\title{
Thermal decomposition and spectral characterization of di[carbonatot etraamminecobalt(III)] sulfate trihydrate and the nature of its thermal decomposition products
}

\author{
Fernanda Paiva Franguelli ${ }^{1,6} \cdot$ Berta Barta-Holló $^{2} \cdot$ Vladimir M. Petruševski $^{3} \cdot$ Istvan E. Sajó $^{4} \cdot$ Szilvia Klébert $^{1}$. \\ Attila Farkas ${ }^{5} \cdot$ Eszter Bódis $^{1} \cdot$ Imre Miklós Szilágyi $^{6} \cdot$ Rajendra P. Pawar $^{7} \cdot$ László Kótai $^{1,8}$
}

Received: 24 May 2020 / Accepted: 22 June 2020 / Published online: 13 July 2020

(c) The Author(s) 2020

\begin{abstract}
Detailed vibrational (IR, Raman, far-IR) and thermal (TGA, TG-MS, DSC) analysis has been performed on di $\left[\kappa^{1} \mathrm{O}, \mathrm{\kappa}^{2} \mathrm{O}-\mathrm{car}\right.$ bonatotetraamminecobalt(III)] sulfate trihydrate, $\left(\left[\mathrm{Co}\left(\mathrm{NH}_{3}\right)_{4} \mathrm{CO}_{3}\right]_{2} \mathrm{SO}_{4} \cdot 3 \mathrm{H}_{2} \mathrm{O}(\mathbf{1})\right.$. Its isothermic heating at $100{ }^{\circ} \mathrm{C}$ leads to formation of $\left[\mathrm{Co}\left(\mathrm{NH}_{3}\right)_{4} \mathrm{CO}_{3}\right]_{2} \mathrm{SO}_{4}$ (compound 2). UV and IR studies showed that the distorted octahedral arrangement around cis- $\mathrm{O}_{2} \mathrm{CoN}_{4}$ core in compound $\mathbf{1}$ does not change during dehydration, which explains the reversible water loss and ability of compound 2 to rehydrate into compound $\mathbf{1}$. Compound $\mathbf{2}$ decomposes at $\sim 240{ }^{\circ} \mathrm{C}$ in inert atmosphere giving final decomposition products, which are two modifications of nanosized metallic cobalt (hcp-15 nm, fcc- $250 \mathrm{~nm})$ and CoO (55 nm). The redox reaction results in $\mathrm{N}_{2}$ as an ammonia oxidation product. The decomposition intermediate is a cobalt(II) compound, $\mathrm{Co}_{2} \mathrm{O}_{1,14+\delta}\left(\mathrm{SO}_{4}\right)_{0.86}(\delta=$ the oxygen surplus due to the presence of $2.8 \%$ of $\mathrm{Co}(\mathrm{III})$ ion). The same reaction in air atmosphere resulted in $\mathrm{Co}_{2} \mathrm{O}_{1.25+\delta}\left(\mathrm{SO}_{4}\right)_{0.75}$ ( $\delta=$ the oxygen surplus due to the presence of $5.3 \%$ of $\mathrm{Co}$ (III) ion (compound 3a). Compound 3a is oxidized in air at $793{ }^{\circ} \mathrm{C}$ into $\mathrm{Co}_{3} \mathrm{O}_{4}$. The compound 3a exhibits catalytic activity in photodegradation in Congo red. The photodegradation process follows pseudo-first-order kinetic ( $k_{\text {app }}=1.0$ and 7.0. at $\mathrm{pH}=3.4$ and 5.25, respectively).
\end{abstract}

Keywords di $\left[\kappa^{1} \mathrm{O}, \kappa^{2} \mathrm{O}\right.$-carbonatotetraamminecobalt(III) $]$ sulfate trihydrate $\cdot$ Evolved gas analysis $\cdot$ Redox reaction . Thermal analysis $\cdot$ Photocatalysis

Fernanda Paiva Franguelli

fernandapaivafranguelli@mail.bme.hu

1 Institute of Materials and Environmental Chemistry, Research Centre for Natural Sciences, ELKH, Budapest 1117, Hungary

2 Department of Chemistry, Biochemistry and Environmental Protection, Faculty of Sciences, University of Novi Sad, Trg Dositeja Obradovića 3, Novi Sad 21000, Serbia

3 Faculty of Natural Sciences and Mathematics, Ss. Cyril and Methodius University, Skopje, Republic of Macedonia

4 János Szentágothai Research Centre, University of Pécs, Ifjúság útja 20, Pecs 7624, Hungary

5 Department of Organic Chemistry and Technology, Budapest University of Technology and Economics, Budafoki út 8, Budapest 1111, Hungary

6 Department of Inorganic and Analytical Chemistry, Budapest University of Technology and Economics, Muegyetem rakpart 3, Budapest 1111, Hungary

7 Department of Chemistry, Deogiri College, Station Road, Aurangabad, Maharashtra 431 005, India

8 Deuton-X Ltd., Selmeci u. 89, Érd 2030, Hungary

\section{Introduction}

To continue our studies on the solid-phase quasi-intramolecular redox reactions between complex cations having redoxactive ligands or cations [1-8], our next target was the preparation of $\left[\mathrm{Co}\left(\mathrm{NH}_{3}\right)_{4} \mathrm{CO}_{3}\right]\left(\mathrm{XO}_{4}\right)_{\mathrm{n}}(\mathrm{X}=$ oxidizing tetrahedral anion) type compounds as precursors for the preparation of various Co oxide catalysts $[9,10]$. The [carbonatotetraammi necobalt(III)] sulfate trihydrate, $\left(\left[\mathrm{Co}\left(\mathrm{NH}_{3}\right)_{4} \mathrm{CO}_{3}\right]_{2} \mathrm{SO}_{4} \cdot 3 \mathrm{H}_{2} \mathrm{O}\right.$ (1) has been known for a long time [11] and used as a watersoluble ( $s \geq 60.61 \mathrm{~g} \mathrm{~L}^{-1}[12]$ ) ionic sulfate compound as a precursor for the preparation of other type Co-complexes [13], or as a reagent in the detection of proteins [14] and for feeding of fungi [15] as well. Some of the early investigators described the crystals of compound $\mathbf{1}$ with very different habit and structure as rhombohedral [16], orthorhombic [17] or monoclinic $[18,19]$ material. The single-crystal study confirmed the existence of the monoclinic form of compound 1 [20] at room temperature. 
Amigo et al. [21] studied the decomposition of compound 1 in air until $800{ }^{\circ} \mathrm{C}$, while Onodera et al. [22] combined TG, DSC and GC studies performed in inert atmosphere till $400{ }^{\circ} \mathrm{C}$. The results given in these papers are very different, which indicates that the nature of the atmosphere has a crucial influence on the decomposition pathway. The diversity of crystal habits and the contrary information about the thermal behavior of compound $\mathbf{1}$ initiated us to study the existence of polymorphism and thermal behavior of it, including the identification of thermal decomposition products and intermediates as well.

In this work, the thermal decomposition characteristics of compound $\mathbf{1}$ in air and inert atmosphere with DSC and TG-MS were studied in detail. The nature of decomposition products and the influence of the atmosphere on the decomposition processes were also studied. The compound 1, its dehydrated form ( $\left[\mathrm{Co}\left(\mathrm{NH}_{3}\right)_{4} \mathrm{CO}_{3}\right]_{2} \mathrm{SO}_{4}$, compound 2) and the earlier unknown thermal decomposition intermediate formed in the decomposition of compound $\mathbf{1}$ in air (basic cobalt(II) sulfate, $\mathrm{Co}_{2} \mathrm{O}_{1.25+\delta}\left(\mathrm{SO}_{4}\right)_{0.75}, \delta=$ the oxygen surplus due to presence of $5.3 \%$ of $\mathrm{Co}$ (III) ion in the compound), compound 3a) were characterized by spectroscopic methods. The photocatalytic activity of compound $\mathbf{3 a}$ on the degradation of toxic dyes is presented.

\section{Experimental}

Deuton-X Ltd., Hungary, supplied chemical-grade cobalt carbonate, ammonium hydroxide (25\%) and ammonium carbonate, hydrogen peroxide (30\%) and analytical grade of perchloric acid, sodium hydroxide, ethanol, barium hydroxide, barium nitrate, hexachloroplatinic acid hexahydrate, basic cobalt(II) carbonate and sulfuric acid.

\section{Preparation}

To prepare compound $\mathbf{1}$, a modified method described by Jorgensen [25] was followed by dissolving $20 \mathrm{~g}$ of cobalt carbonate in dilute $\mathrm{H}_{2} \mathrm{SO}_{4}(10 \%)$, reaching a total volume of $100 \mathrm{~mL}$. Then, the clear solution was poured into a solution containing $100 \mathrm{~g}$ of $\left(\mathrm{NH}_{4}\right)_{2} \mathrm{CO}_{3}$, and $500 \mathrm{~mL}$ of distilled water and $250 \mathrm{~mL}$ of cc. ammonia and oxidation were performed during 3-4 h through a constant oxygen stream system. After the oxidation step was finished, a blood-red solution was expected to contain several small pieces of $\left(\mathrm{NH}_{4}\right)_{2} \mathrm{CO}_{3}$. Evaporation proceeded on a steam bath until it reaches the volume of $300 \mathrm{~mL}$, and then, the solution was filtered out. The solution was evaporated again to turn into a more concentrated form $(200 \mathrm{~mL})$ and chilled out, whereupon $\left[\mathrm{Co}\left(\mathrm{NH}_{3}\right)_{4} \mathrm{CO}_{3}\right]_{2} \mathrm{SO}_{4} \cdot 3 \mathrm{H}_{2} \mathrm{O}$ crystallizes as purplish-pink prisms. The mother liquor was decanted, and the precipitates were filtered off (washed with a saturated solution containing a small portion of the precipitate). Further evaporation of the mother liquor resulted in more salt formation. It is essential to add some $\left(\mathrm{NH}_{4}\right)_{2} \mathrm{CO}_{3}$ during the evaporation step.

The anhydrous salt (compound $\mathbf{2}$ ) was prepared with isothermal heating of compound 1 at $120^{\circ} \mathrm{C}$ for $2 \mathrm{~h}$ in air. Similarly, the compounds $\mathbf{3 a}$ and $\mathbf{3 b}$ were prepared at $300{ }^{\circ} \mathrm{C}$ in air or $\mathrm{N}_{2}$, respectively, for $2 \mathrm{~h}$ in both cases.

\section{Elemental analysis}

The sulfate ion content was determined gravimetrically. Dissolution of ca. $1 \mathrm{~g}$ precisely weighted sample in $20 \mathrm{~mL}$ water, precipitating the barium sulfate in a usual way with 2 equivalent of barium nitrate dissolved in water. The processing was done in the usual way [30]. To determine ammonia and carbonate content in the compound $\mathbf{1}$, the solid compound 1 was put into a three-necked flask equipped with a thermometer and dropping funnel, and $20 \mathrm{~mL}$ of $10 \%$ of $\mathrm{NaOH}$ solution was added dropwise under heating to release all the ammonia from the solution. The evolved ammonia was absorbed and precipitated as ammonium hexachloroplatinate, filtered off and heated at $500{ }^{\circ} \mathrm{C}$ to transform that into metallic platinum. The solution left back contains cobalt(III) hydroxide precipitate and sodium carbonate was acidified, and the liberated $\mathrm{CO}_{2}$ was precipitated with $\mathrm{Ba}(\mathrm{OH})_{2}$ as $\mathrm{BaCO}_{3}$ and measured according to the usual way [30]. The cobalt content of the solution was measured as $\mathrm{Co}_{3} \mathrm{O}_{4}$, oxidizing the cobalt content of the sample (in case of compound $\mathbf{3}$ after dissolution in perchloric acid) with sodium peroxodisulfate then precipitating the $\mathrm{Co}(\mathrm{OH})_{3}$ and heating that at $950{ }^{\circ} \mathrm{C}$ for $2 \mathrm{~h}$. The cobalt(III) content determination has been done according to the known method with iodometry [31]. The ammonium sulfate content of the samples was decomposed by boiling them with $10 \%$ aq. $\mathrm{NaOH}$ solution for 30 min under $\mathrm{N}_{2}$ atmosphere.

\section{Instrumental methods}

X-ray powder diffraction measurements were taken using a Philips PW-1050 Bragg-Brentano parafocusing goniometer. It was equipped with a $\mathrm{Cu}$ tube operated at $40 \mathrm{kV}$ and $35 \mathrm{~mA}$ tube power, a secondary beam graphite monochromator and a proportional counter. Scans were recorded in step mode with $0.04^{\circ}$ step size for $1 \mathrm{~s}$ between $25^{\circ}$ and $65^{\circ} 2 \theta$. Evaluation of the diffraction patterns had been obtained by full profile fitting techniques. The in situ, high-temperature XRD measurements were taken in a nitrogen atmosphere in a high-temperature HTK-1200 Anton-Paar chamber with temperature programming, at 450,550 and $800^{\circ} \mathrm{C}$, respectively.

FTIR measurements were recorded on a Jasco FT/ IR-4600 system, equipped with a Jasco ATR Pro One single reflection diamond ATR accessory (incident angle $45^{\circ}$ ), and 
a DLATGS detector in the $4000-400 \mathrm{~cm}^{-1}$ region. A resolution of $4 \mathrm{~cm}^{-1}$ and co-addition of 64 individual spectra was applied. Before the evaluation, an ATR correction (Jasco Spectra Manager version 2, Spectra analysis module version 2.15.11) was performed on the raw spectra. Far-IR spectra were recorded on a BioRad-Digilab FTS-60A spectrometer with 6.25 Mylar beamsplitter equipped with Pike GladiATR accessory with diamond ATR crystal for the $700-40 \mathrm{~cm}^{-1}$ range in Nujol mull.

The Raman measurements were taken using Horiba Jobin-Yvon LabRAM-type microspectrometer with external $532 \mathrm{~nm}$ Nd-YAG $(\sim 40 \mathrm{~mW})$ and 785 diode laser sources $(\sim 50 \mathrm{~mW})$ and Olympus BX-40 optical microscope. Optional optical density filters $(D=0.3$ and 0.6$)$ were applied to decrease laser light intensity avoiding the thermal degradation of samples. The laser beam was focused by an objective of $20 \times(\mathrm{NA}=0.4)$. The confocal hole of $1000 \mu \mathrm{m}$ and 950 (for $785 \mathrm{~nm}$ light) and 1800 groove $\mathrm{mm}^{-1}$ (for $532 \mathrm{~nm}$ light) grating monochromators were used in a confocal system and for light dispersion. In the case of $532 \mathrm{~nm}$ excitation, the spectral range of $100-4000 \mathrm{~cm}^{-1}$ was detected as the relevant range with $3 \mathrm{~cm}^{-1}$ resolution collecting the spectrum for $120 \mathrm{~s}$ per point. In the case of $785 \mathrm{~nm}$ excitation, the measured spectral range was between 100 and $2400 \mathrm{~cm}^{-1}$ with $5 \mathrm{~cm}^{-1}$ resolution and the exposure time of the sample was $30 \mathrm{~s}$.

Thermal data in air and nitrogen were collected using TA Instruments SDT Q600 thermal analyzer coupled to Hiden Analytical HPR-20/QIC mass spectrometer. The decomposition was followed from room temperature to $500{ }^{\circ} \mathrm{C}$ at $10 \mathrm{~K} \mathrm{~min}^{-1}$ heating rate in nitrogen and air as carrier gas (flow rate $=50 \mathrm{~cm}^{3} \mathrm{~min}^{-1}$ ). Sample holder/reference: alumina crucible/empty alumina crucible. Sample mass 1-2 mg. The coupled TG-MS measurements were taken by heating rate $5 \mathrm{~K} \mathrm{~min}^{-1}$ in argon and air. Selected ions between $m / z=1-97$ were monitored in Multiple Ion Detection Mode (MID).

Simultaneous thermogravimetric, differential scanning calorimetric and mass spectrometric evolved gas analysis (TG-DSC-MS) measurements under inert conditions were taken on a Setaram LabsysEvo thermal analyzer, in high-purity helium (6.0) atmosphere, with a flow rate of $90 \mathrm{~mL} \mathrm{~min}{ }^{-1}$. The measurements were recorded in the $25-500{ }^{\circ} \mathrm{C}$ temperature range, with a heating rate, of $20{ }^{\circ} \mathrm{C} \mathrm{min}^{-1}$, and samples were weighed into $100-\mu \mathrm{L}$ alumina crucibles. The obtained data were baseline corrected and further evaluated by the thermoanalyzer's processing software (Calisto Processing, ver. 2.01). Parallel to the TG-DSC measurement, the analysis of the evolved gases/ decomposition products was carried out on a Pfeiffer Vacuum OmniStar ${ }^{\mathrm{TM}}$ quadrupole mass spectrometer coupled to the above-described TGA. The gas splitters and transfer lines to the spectrometer were thermostated to $220^{\circ} \mathrm{C}$. The measurements were taken in SEM Bargraph Cycles acquisition mode, in which the total ion current (TIC), the analog bar graph spectra (for structure determination) and the separate ion current of each scanned individual mass (96 masses) were recorded. The scanned mass interval was 5-100 amu, with a scan speed of $20 \mathrm{~ms} \mathrm{amu}^{-1}$, and the spectrometer was operated in electron impact mode.

Nitrogen physisorption measurements using Quantachrome Autosorb 1C static volumetric apparatus at $-196{ }^{\circ} \mathrm{C}$. Samples of cc. $0.1 \mathrm{~g}$ were outgassed under vacuum before measures at $110^{\circ} \mathrm{C}$ for $24 \mathrm{~h}$. The specific surface area was calculated by the BET method.

The morphologies of the product were studied by ZEISS EVO 40XVP scanning electron microscope (SEM) operating at $20 \mathrm{kV}$. The SEM measurements were taken with different magnifications.

\section{Photocatalysis}

To evaluate the photocatalytic activity of the compounds 3a and $\mathrm{Co}_{3} \mathrm{O}_{4}$ prepared at 300 and $750{ }^{\circ} \mathrm{C}$, respectively, under an oxidizing atmosphere, $1.0 \mathrm{mg}$ of each Co-containing material was put into $3 \mathrm{~mL}$ of an aqueous solution of Methyl Orange $\left(4 \times 10^{-5} \mathrm{M}\right)$ and Congo Red $\left(2 \times 10^{-5} \mathrm{M}\right)$ dyes by using quartz cuvettes. The samples were kept in the dark overnight for the adsorption equilibrium. After that, they were submitted to a UV radiation source by Osram 18 -W blacklight lamps ( $\lambda=$ maximum intensity at $375 \mathrm{~nm}$ ). The cuvettes were placed $5 \mathrm{~cm}$ from each lamp, and the absorbance was measured every 30 min during $4 \mathrm{~h}$ by a Jasco V-550 UV-Vis spectroscope. The relative absorbance values of the most intensive peaks for Methyl Orange $(464 \mathrm{~nm})$ at pH 5.60 and Congo Red $(497 \mathrm{~nm})$ at pH 5.73 were considered to evaluate the catalysts' activity in the degradation of dyes.

\section{Preparation and properties of compounds 1, 2 and 3}

The compound 1 was prepared first by Vortman [11,23] in the reaction of basic cobalt carbonate with ammonia and ammonium carbonate on heating in air for 2 days, reacting the formed mixture with cold dilute sulfuric acid. The elemental analysis showed that compound $\mathbf{1}$ crystallizes with three molecules of water per formula unit confirmed by Benrath and Kohlberg [24] by vapor pressure measurements. Jörgensen [25] improved the method, adding cobaltous carbonate dissolved in diluted sulfuric acid to a solution of aqueous $\mathrm{NH}_{3}$-ammonium carbonate mixture, passing a current of air through the liquid for 2-3 h. Uspensky and Chibisov [26] obtained compound $\mathbf{1}$ by passing carbon dioxide gas into an aqueous solution of diaquotetraamminecobalt sulfate, in the presence of calcium carbonate. The purity of compound $\mathbf{1}$ depends heavily on the experimental 
conditions because the isomeric $\left(\mathrm{Co}\left(\mathrm{NH}_{3}\right)_{4} \mathrm{SO}_{4}\right] \mathrm{CO}_{3} \cdot 2 \mathrm{H}_{2} \mathrm{O}$ [23, 27], and diaquotetraamminecobalt(III) sulfate/carbonate compounds [28, 29] or penta- and hexaamminecobalt(III) compounds with carbonate and sulfate counter ions [25] are also formed under similar experimental conditions. In our experimental methodology, the Jörgensen's method [25] was modified by bubbling oxygen gas instead of air. The rubyred crystals showed strong pleochroic behavior-the color parallel to (100) is purple-red while that parallel to $(010)$ is brownish-red with a purple tinge, and that parallel to (001) is brownish-red [18]. The low-temperature DSC results under helium showed that the compounds $\mathbf{1}$ had not been any polymorphs between $-150{ }^{\circ} \mathrm{C}$ and its thermal decomposition point.

The composition and purity of compound $\mathbf{1}$ were checked by elemental analysis, XRD and IR spectroscopy to disclose the presence of others, e.g., sulfate-coordinated isomers. The ammonia complexes of cobalt(III) ion are stable enough toward hydrolysis; thus, the sulfate content could be measured directly as $\mathrm{BaSO}_{4}[23,30]$. The solution of compound $\mathbf{1}$ was decomposed with $\mathrm{NaOH}$, and the liberated ammonia was precipitated as ammonium hexachloroplatinate [30]. The $\mathrm{CO}_{2}$ evolved on acidifying of mother liquor was measured as $\mathrm{BaCO}_{3}$ [30]. To determine the cobalt(III) content, the residual mother liquor was treated with sodium peroxidisulfate and $\mathrm{NaOH}$, and the formed brown precipitate was measured as $\mathrm{Co}_{3} \mathrm{O}_{4}$ after heating at $950{ }^{\circ} \mathrm{C}$ for $2 \mathrm{~h}$ [30]. Compound 2 was analyzed in the same way, while compound $\mathbf{3}$ was dissolved in perchloric acid, and the cobalt(III) content was measured by iodometry [31].

\section{Spectroscopic characterization (IR, far-IR, UV, Raman) of compound 1}

The IR band assignations of the complex cation and the sulfate anion in complex 1 have already been published by Siebert [32] and Goldschmidt et al. [33, 34]. However, there have been no Raman measurements and factor group analysis on compound $\mathbf{1}$. The ammonia ligands coordinated to the cobalt(III)-ion forms hydrogen bonds with the sulfate and carbonate ions, determined from the values of the refractive indices [35], spin-lattice relaxation times/ammonia ligand reorientation energies [36] and single-crystal studies [20] as well. It can cause symmetry lowering, and thus, the number and types of vibrational modes for the cationic $\left(\left[\mathrm{Co}\left(\mathrm{NH}_{3}\right)_{4} \mathrm{CO}_{3}\right]^{+}\right)$, anionic $\left(\mathrm{SO}_{4}^{2-}\right)$ and crystallization water $\left(\mathrm{H}_{2} \mathrm{O}\right)$ parts of the compound $\mathbf{1}$ were predicted by the factor group method. For the factor group analysis, the exact space group $\left(\mathrm{P} 2{ }_{1} / \mathrm{c}\right)$ was taken from [20].

\section{Vibrational modes of the cation}

Octahedral skeleton The cationic part of compound $\mathbf{1}$ has octahedral cis- $\mathrm{O}_{2} \mathrm{CoN}_{4}$ type coordination structure (distortion of $\mathrm{CO}_{3}^{2}$-ion symmetry from $D_{3 \mathrm{~h}}$ to $C_{2 \mathrm{v}}$ ), the carbonato group fills two coordination sites, and the other four coordination sites are occupied with ammonia molecules. There are two different crystallographic types of central cobalt(III) ions. Thus, the total number of modes for the $\mathrm{Co}^{3+}$ cations is doubled and equals $2 \times(4 \times 3)=24$ translational degrees of freedom (Fig. 1). All modes are Raman and IR active (Fig. 1).

There are three types of stretching and bending modes for a cis- $\mathrm{O}_{2} \mathrm{CoN}_{4}$ type octahedral cation ( $\mathrm{NCoN}, \mathrm{NCoO}$ and $\mathrm{OCoO}$ ), which have considerable coupling [33]. The measured far-IR and Raman spectroscopic data and the calculated frequency values for an isolated $\left[\mathrm{Co}\left(\mathrm{NH}_{3}\right)_{4} \mathrm{CO}_{3}\right]^{+}$ion $\left(f_{\mathrm{CoN}}=1.6\right.$ and $\left.f_{\mathrm{CoO}}=1.25[33]\right)$ are given in Table 1.

These assignments are reasonable as tentative assignments, based on the common assumption that $\mathrm{M}-\mathrm{N}$ stretchings are higher than the corresponding $\mathrm{M}-\mathrm{O}$ stretchings. Logically, for the stretchings of $\mathrm{MN}_{2}, \mathrm{MO}_{2}$ and $\mathrm{MON}$, one would expect the following order of wavenumbers $\nu_{\mathrm{s}}(\mathrm{NMN})>\nu_{\mathrm{s}}(\mathrm{NMO})>\nu_{\mathrm{s}}(\mathrm{OMO})$, and also $\nu_{\mathrm{as}}>\nu_{\mathrm{s}}$ for all of the above species. The $\mathrm{CoO}_{2}$ moiety $\left(C_{2 \mathrm{v}}\right)$ in $\left[\mathrm{Co}\left(\mathrm{NH}_{3}\right)_{4} \mathrm{CO}_{3}\right]^{+}$complexes have higher wavenumbers for antisymmetric $\mathrm{Co}-\mathrm{O}$ stretching frequency values than symmetric $\mathrm{Co}-\mathrm{O}$ one $[33,38]$, thus among the two observed one, the band observed at $396 \mathrm{~cm}^{-1}$ in IR and $404 \mathrm{~cm}^{-1}$ in Raman spectra were assigned as the antisymmetric while the lower frequency bands at 335 and $318 \mathrm{~cm}^{-1}$ in the IR and Raman spectra, respectively, were assigned as the bands of the symmetric $\mathrm{Co}-\mathrm{O}$ mode. Each $\mathrm{Co}-\mathrm{N}$ band belongs to $\mathrm{CoN}_{2}$, and CoNO moieties cannot be distinguished unambiguously, partly due to symmetry lowering of the regular octahedron, which contains cis-coordinated carbonato-group, and partly due to the differences in $\mathrm{Co}-\mathrm{N}$ and $\mathrm{Co}-\mathrm{O}$ bond distances and consequently the mixed character of these bands.

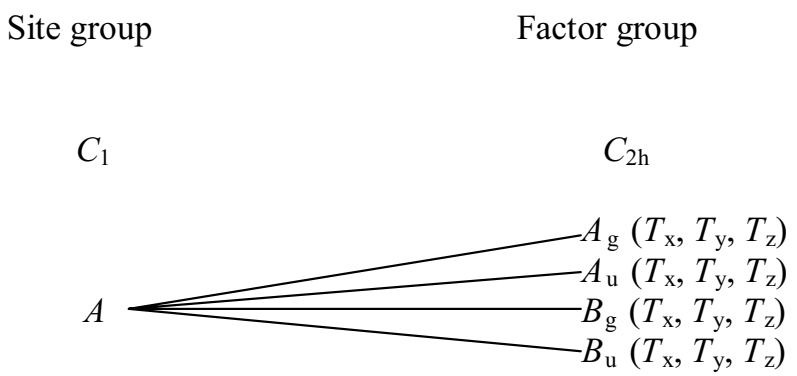

Fig. 1 Factor group analysis results of central $\mathrm{Co}^{3+}$ cation in compound 1 
Table 1 cis- $\mathrm{O}_{2} \mathrm{CoN}_{4}$ skeleton internal vibrational modes and their tentative assignation in the far-IR and Raman spectra of compound 1

\begin{tabular}{|c|c|c|c|c|c|c|}
\hline \multirow[t]{3}{*}{ Species } & \multirow[t]{3}{*}{ Band } & \multicolumn{3}{|c|}{ Measured $/ \mathrm{cm}^{-1}$} & \multirow{3}{*}{$\begin{array}{l}\text { Calculated } / \mathrm{cm}^{-1} \\
{[33]}\end{array}$} & \multirow[t]{3}{*}{ Assignation } \\
\hline & & \multicolumn{2}{|l|}{ IR } & \multirow[t]{2}{*}{ Raman* } & & \\
\hline & & Our & {$[33]$} & & & \\
\hline \multirow[t]{6}{*}{$A_{1}$} & $\nu_{1}$ & 514 & 513 & 514 & 527 & $\nu_{\mathrm{CoN}}$ \\
\hline & $\nu_{2}$ & 430 & 437 & 442 & 430 & $\nu_{\mathrm{CoN}}$ \\
\hline & $\nu_{3}$ & 326 & $304 \mathrm{sh}$ & - & 308 & $\delta$ \\
\hline & $\nu_{4}$ & - & - & - & 149 & $\delta$ \\
\hline & $\nu_{5}$ & - & - & - & 38 & $\delta$ \\
\hline & $\nu_{6}$ & 400 & 396 & 404 & 396 & $\nu_{\text {as }}(\mathrm{CoO})$ \\
\hline \multirow[t]{3}{*}{$B_{1}$} & $\nu_{9}$ & 484 & 501 & 473 & 496 & $\nu_{\mathrm{CoN}}$ \\
\hline & $\nu_{10}$ & 286 & $293 \mathrm{sh}$ & 293 & 273 & $\delta$ \\
\hline & $\nu_{11}$ & 204 & - & 204 & 201 & $\delta$ \\
\hline \multirow[t]{4}{*}{$B_{2}$} & $\nu_{12}$ & 440 & 437 & 442 & 459 & $\nu_{\mathrm{CoN}}$ \\
\hline & $\nu_{13}$ & - & 194sh & 203 & 191 & $\delta$ \\
\hline & $\nu_{14}$ & 336 & $335 \mathrm{sh}$ & - & 318 & $\nu_{\mathrm{s}}(\mathrm{CoO})$ \\
\hline & $\nu_{15}$ & 130 & 140sh & 141 & 129 & $\delta$ \\
\hline
\end{tabular}

*785 nm excitation wavelength

\section{Vibrational modes of the coordinated ammonia in com-} pound 1 Due to the two crystallographic different $\left[\mathrm{Co}\left(\mathrm{NH}_{3}\right)_{4} \mathrm{CO}_{3}\right]^{+}$cation of the structure, eight crystallographic different ammonia molecules could be distinguished. There are four internal vibrational modes of $\mathrm{NH}_{3}$ molecules under $C_{3 \mathrm{v}}$ symmetry, $\nu_{1}$ is the symmetric stretching vibration $\left(\nu_{\mathrm{s}}\right)\left(A_{1}\right) ; \nu_{2}$ is the symmetric bending $\left(\delta_{\mathrm{s}}\left(A_{1}\right)\right.$; $\nu_{3}$ is the antisymmetric stretching vibration $\left(\nu_{\mathrm{as}}(\mathrm{E}) ; \nu_{4}\right.$ is the antisymmetric bending [ $\delta_{\text {as }}\left(\right.$ E) (Fig. 2)]. The $\nu_{3}, \nu_{4}$ and $T_{\text {xy }}$ and $R_{\mathrm{xy}}$ external mode are doubly degenerated modes under $C_{3 \mathrm{v}}$ while $T_{\mathrm{z}}$ and $R_{\mathrm{z}}$ are non-degenerated ones) (ESI Fig. 1).

The total number of factor group modes due to the internal and external vibrations is the same, $8 \times 24$ for eight crystallographic types of $\mathrm{NH}_{3}$ in each case that is equal to 192 internal and 192 external (96 due to hindered translation and 96 due to hindered rotations) vibrational degrees of freedom. The degeneracies are lifted, and all the modes are IR and Raman active. The rocking mode of $\mathrm{NH}_{3}\left(\nu_{5}(\mathrm{E})\right.$, $\left.\rho\left(\mathrm{NH}_{3}\right)\right)$ belongs to the $\mathrm{Co}-\mathrm{NH}_{3}$ fragment, and the $\nu_{\mathrm{s}}(\mathrm{CoN})$ (A1) mode of this fragment is discussed among translational modes of $\mathrm{Co}^{3+}$ ion (Table 2).

Using a laser with a $785 \mathrm{~nm}$ excitation beam did not give $\mathrm{NH}$ band intensities enough to evaluate, but at $532 \mathrm{~nm}$ excitation, we could get a Raman spectrum in the range of $\mathrm{NH}$ bond modes. The broad bands of symmetric and antisymmetric NH modes are strongly overlapped (Table 2). The Raman spectra recorded at $532 \mathrm{~nm}$ excitation gave a combined band containing symmetric $\mathrm{HNH}$ bending and antisymmetric $\mathrm{CO}$ stretching modes as a complex band system at $1293 \mathrm{~cm}^{-1}$. In the Raman spectra recorded at $785 \mathrm{~nm}$, only the Co-O antisymmetric stretching mode component of the band system appears and is centered at $1273 \mathrm{~cm}^{-1}$. It is confirmed

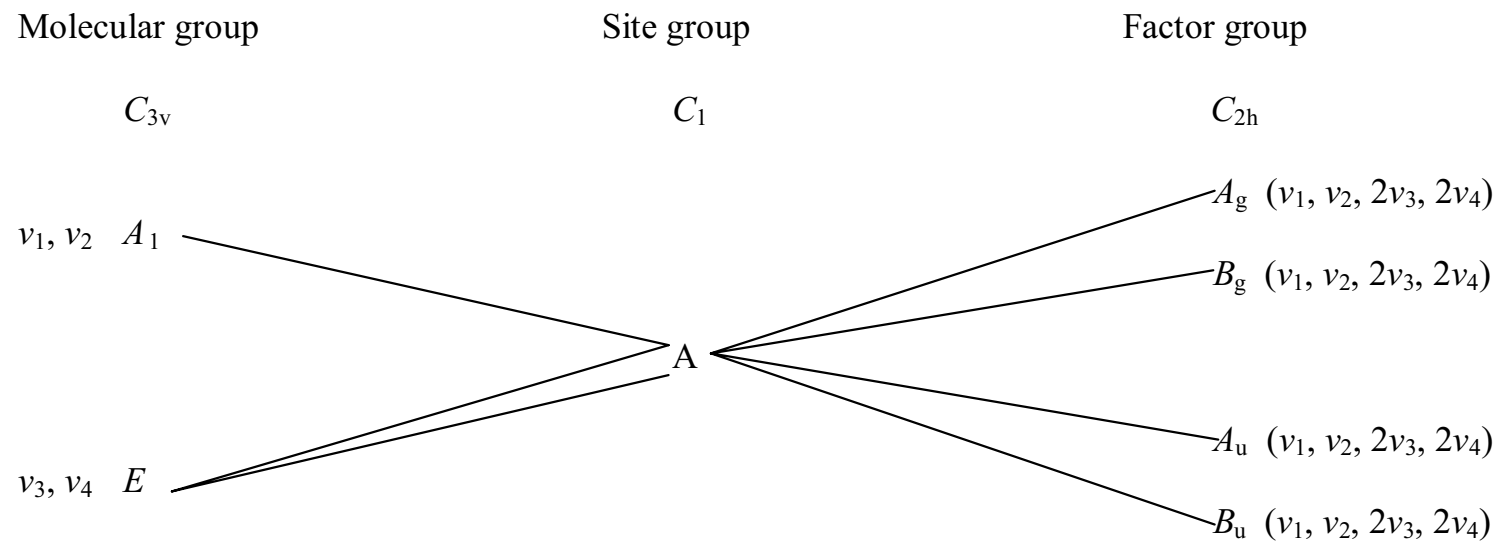

Fig. 2 Factor group analysis of internal modes of ammonia molecules (eight types) in compound $\mathbf{1}$ 
Table 2 Ammonia internal vibrational modes and their assignation in the IR and Raman spectra of compound 1 and perdeuterated 1

\begin{tabular}{|c|c|c|c|c|c|c|c|}
\hline \multirow[t]{3}{*}{ Species } & \multirow[t]{3}{*}{ Band } & \multicolumn{5}{|c|}{ Measured $/ \mathrm{cm}^{-1}$} & \multirow[t]{3}{*}{ Assignation } \\
\hline & & \multicolumn{4}{|l|}{ IR } & \multirow[b]{2}{*}{$\operatorname{Raman} * * *$} & \\
\hline & & [33] & {$[32]$} & Our results & After deuteration & & \\
\hline \multirow[t]{2}{*}{$A_{1}$} & $\nu_{1}$ & - & 3290,3180 & 3289,3192 & 2318,2286 & $3235,3175 \mathrm{sh}$ & $\nu_{\mathrm{s}}(\mathrm{NH})$ \\
\hline & $\nu_{2}$ & 1300 & 1320,1279 & 1300 & 1004,1020 & 1293 & $\delta_{\mathrm{s}}(\mathrm{HNH})$ \\
\hline \multirow[t]{3}{*}{$E$} & $\nu_{3}$ & - & & 3425 & $2453 * *$ & 3439 & $\nu_{\mathrm{as}}(\mathrm{NH})$ \\
\hline & $\nu_{4}$ & $1638^{*}$ & $1606^{*}$ & $1645^{*}$ & 1162 & $1628 *$ & $\delta_{\text {as }}(\mathrm{HNH})$ \\
\hline & $\nu_{5}$ & 810 & 846 & 828 & 677 & 793 & $\rho\left(\mathrm{NH}_{3}\right)$ \\
\hline
\end{tabular}

*Mixed band with $\nu\left(\mathrm{C}=\mathrm{O}^{\S}\right)$; **Mixed with $\mathrm{D}_{2} \mathrm{O}$ stretching modes; ***535 nm excitation; §-non-coordinated $\mathrm{C}=\mathrm{O}$ bond by the shifting of HNH mode of the band system centered at $\sim 1300 \mathrm{~cm}^{-1}$ in the IR spectrum (ESI Fig. 2) when a component of the band after deuteration of the sample is left back at $1265 \mathrm{~cm}^{-1}$ (Co-O mode), while the higher wavenumber component is shifted to 1020 and $1004 \mathrm{~cm}^{-1}$ (symmetric $\mathrm{ND}_{2}$ bending mode).

The $\mathrm{C}=\mathrm{O}^{\S}$ and $\delta_{\text {as }}(\mathrm{HNHN})$ mixed band centered at $1645 \mathrm{~cm}^{-1}$ decomposes into components on deuteration, and the $\mathrm{C}=\mathrm{O}^{\S}$ component is located at $\sim 1628 \mathrm{~cm}^{-1}$ in the perdeuterated 1 , while the $\mathrm{ND}_{2}$ symmetric bending mode appears at $1162 \mathrm{~cm}^{-1}$. It means the $\delta_{\text {as }}\left(\mathrm{NH}_{2}\right)$ component is the higher wavenumber component of the mixed band. The $\mathrm{C}=\mathrm{O}^{\S}$ component is not sensitive on deuteration, and the deuteration caused only $1 \mathrm{~cm}^{-1}$ shift on the $\mathrm{C}=\mathrm{O}^{\S}$ in the band positions of the similar carbonatotetraamminecobalt(III) perchlorate complex [38].

Vibrational modes of the carbonate ion in compound 1 The free carbonate ion is planar $\left(\mathrm{D}_{3} \mathrm{~h}\right)$ with four internal normal modes of vibration, namely $\nu_{1}\left(A 1^{\prime}\right),\left(\nu_{\mathrm{s}}(\mathrm{C}-\mathrm{O})\right)$, symmetric stretching), $\nu_{2}\left(A 2^{\prime \prime}\right)$ ( $\pi\left(\mathrm{CO}_{3}\right)$, symmetric bending $), \nu_{3}\left(E^{\prime}\right)$, $\left(\nu_{\text {as }}(\mathrm{CO})\right)$, doubly degenerate antisymmetric stretching) and $\nu_{4}\left(E^{\prime}\right)\left(\delta_{\text {as }}(\mathrm{OCO})\right)$, doubly degenerate antisymmetric bending). The $\nu_{1}, \nu_{3}$ and $\nu_{4}$ are IR, while the $\nu_{1}, \nu_{3}$ and $\nu_{4}$ are Raman active. On coordination, either monodentate or bidentate(chelate) form, the symmetry of carbonate ion is lowered to $C_{2 \mathrm{v}}$, and the selection rules are changed (Fig. 3). External modes of $\mathrm{CO}_{3}{ }^{2-}$ anions under $D_{3 \mathrm{~h}}$ symmetry ( $T$ 's are hindered translations; R's are hindered rotations (librations); modes of any of the $E$-symmetries are doubly degenerate. The results of factor group analysis for the two different types of carbonate ion can be seen on (ESI Fig. 1).

The total number of factor group modes due to the internal (24) and external vibrations (24) of a carbonate anion is $48(24+24)$, but because of two crystallographic types of carbonate anions that equals with $2 \times 48$ vibrational degrees of freedom $(2 \times 24=48$ internal modes and 24 hindered translations and 24 hindered rotations) (Fig. 3, ESI Fig. 1). The degeneracies are lifted, and all internal and external vibrations are both IR and Raman active. The bands belong to the coordinated carbonate ion modes in compound $\mathbf{1}$, and their assignations are listed in Table 3. The stretching modes of non-coordinated oxygen $\left(\nu_{1}\right)$ and coordinated ones $\left(\nu_{2}\left(A_{1}\right)\right.$ and $\nu_{4}(E)$, symmetric and antisymmetric one, respectively) can easily be distinguished. There are two kinds of in-plane OCO deformation mode, one with $\left(\nu_{5}\left(B_{1}\right)\right.$ and one without $\left(\nu_{3}\left(A_{1}\right)\right.$ involving of non-bound oxygen. The wavenumber of the highest stretching wavenumber of carbonate

$\begin{array}{lll}\text { Molecular group } & \text { Site group } & \text { Factor group }\end{array}$

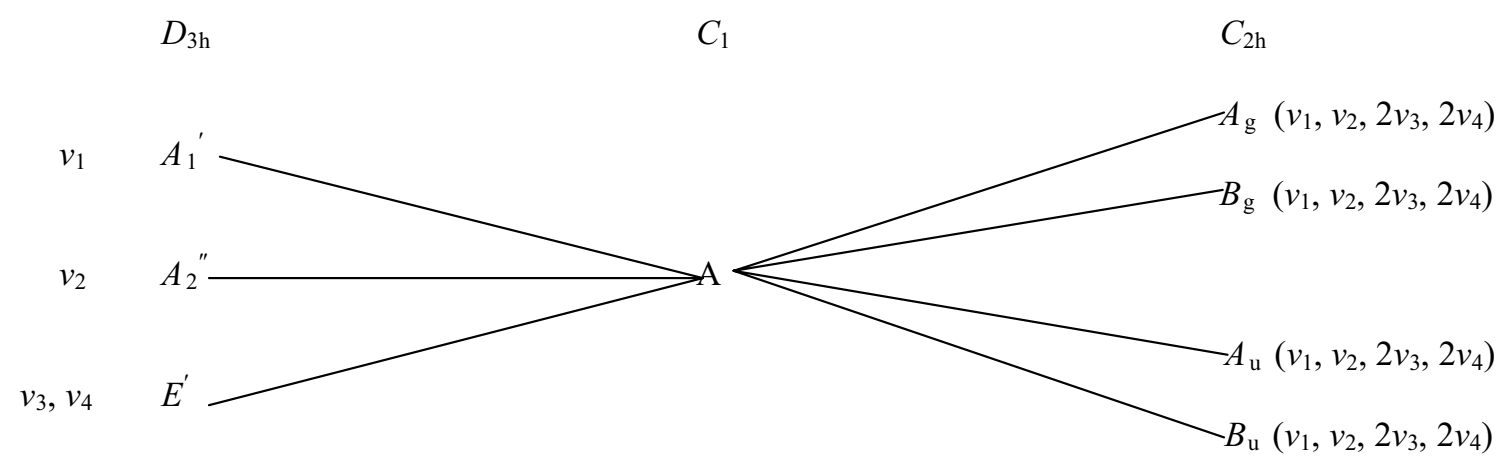

Fig. 3 Factor group analysis of carbonate anions (two types) internal and external vibrations 
Table 3 Chelate coordinated carbonate $\left(C_{2 \mathrm{v}}\right)$ ion internal vibrational modes and their assignation in the IR and Raman spectra of compound $\mathbf{1}$

\begin{tabular}{|c|c|c|c|c|c|c|}
\hline \multirow[t]{2}{*}{ Species } & \multirow[t]{2}{*}{ Band } & \multicolumn{3}{|c|}{ Measured $/ \mathrm{cm}^{-1}$} & \multirow{2}{*}{$\begin{array}{l}\text { Calculated } \\
\text { values } / \mathrm{cm}^{-1} \\
{[34]}\end{array}$} & \multirow[t]{2}{*}{ Assignation } \\
\hline & & IR [34] & IR (our results) & $\begin{array}{l}\text { Raman ( } 785 \mathrm{~nm} \\
\text { excitation wave- } \\
\text { length) }\end{array}$ & & \\
\hline \multirow[t]{3}{*}{$A_{1}$} & $\nu_{1}$ & 1610 & $1613^{*}$ & $1620^{*}$ & 1577 & $\nu\left(\mathrm{C}=\mathrm{O}^{\S}\right)$ \\
\hline & $\nu_{2}$ & 1020 & $1033 \mathrm{sh}$ & 1022 & 1052 & $\nu_{\mathrm{s}}(\mathrm{C}-\mathrm{O})$ \\
\hline & $\nu_{3}$ & 755 & 756 & 758 & 771 & $\delta(\mathrm{OCO})$, in-plane \\
\hline \multirow[t]{3}{*}{$B_{1}$} & $\nu_{4}$ & 1280 & 1300 & 1273 & 1274 & $\nu_{\text {as }}(\mathrm{CO})$ \\
\hline & & 1255 & 1255 & 1253 & & \\
\hline & $\nu_{5}$ & 678 & 675 & 677 & 671 & $\delta\left(\mathrm{OCO}^{\S}\right)$, in-plane \\
\hline \multirow[t]{2}{*}{$B_{2}$} & $\nu_{6}$ & 850 & 853 & & 859 & $\pi$, out-of-plane \\
\hline & & 830 & 828 & & & \\
\hline
\end{tabular}

$\S_{\mathrm{O}}$ means non-coordinated oxygen atom of carbonate ion ion $\left(1610 \mathrm{~cm}^{-1}\right)$ belongs to the non-coordinated $\mathrm{C}=\mathrm{O}$ bond, and the difference between this one and the higher component of the antisymmetric $\mathrm{C}-\mathrm{O}$ (coordinated) mode $\left(\Delta \nu=\sim 330 \mathrm{~cm}^{-1}\right)$ unambiguously show the bidentate coordination mode of carbonate ion in compound $\mathbf{1}$.

The spectroscopic results disclose the monodentate carbonate ion coordination $\left(\nu\left(\mathrm{C}=\mathrm{O}^{\S}\right)\right.$ should be found between 1450 and $1500 \mathrm{~cm}^{-1}$ and $\Delta \nu$ value should not exceed $150 \mathrm{~cm}^{-1}$ ) and the outer sphere non-coordinated mode $\left(D_{3 \mathrm{~h}}\right)$ carbonate ion which would be present in the sulfatecoordinated tetraamminesulfatocobalt(II) carbonate isomer (compound 6) [39].

\section{Vibrational modes of the sulfate anion}

The tetrahedral $\left(T_{\mathrm{d}}\right)$ sulfate anion has four internal vibrational modes, namely the symmetric and antisymmetric S-O stretchings $\left(\nu_{1}\left(A_{1}\right)\right.$ and $\left.\nu_{3}\left(F_{2}\right)\right)$ and the symmetric and antisymmetric SO bending modes $\left(\nu_{2}(E)\right.$ and $\left.\nu_{4}\left(F_{2}\right)\right)$. The symmetric bending mode is doubly, while both antisymmetric modes and the hindered rotations and translations of the sulfate anions are triply degenerate under $T_{\mathrm{d}}$ symmetry. The total number of factor group modes due to the internal $\mathrm{SO}_{4}^{2-}$ vibrations equals 36 vibrational degrees of freedom $(4 \times 9)$.

The total number of factor group modes due to the external $\mathrm{SO}_{4}^{2-}$ vibrations (hindered translations and hindered rotations) equals 24 degrees of freedom (12, for the hindered translations and 12 for the hindered rotations of the sulfate anions). The factor group analysis results for the internal and external mode are summarized in Fig. 4 and ESI Fig. 1, respectively. All four internal and the external modes are IR and Raman active in compound $\mathbf{1}$, and all degeneracies are lifted (Table 4).

The band's singlet nature at $971 \mathrm{~cm}^{-1}$ (IR) with low intensity compared with the intensive Raman bands confirms it as the symmetric S-O stretching mode because of the IR and Raman intensities of $\nu_{\mathrm{s}}$ and $\nu_{\text {as }}$ bands appear in opposite relations in IR and Raman spectra. The symmetric one is weak (or forbidden in the IR) and quite intensive in the Raman spectra, while $\nu_{\text {as }}$ is very intense in IR but very weak in the Raman spectra of tetrahedral ions [1-5, 40]. The intensive

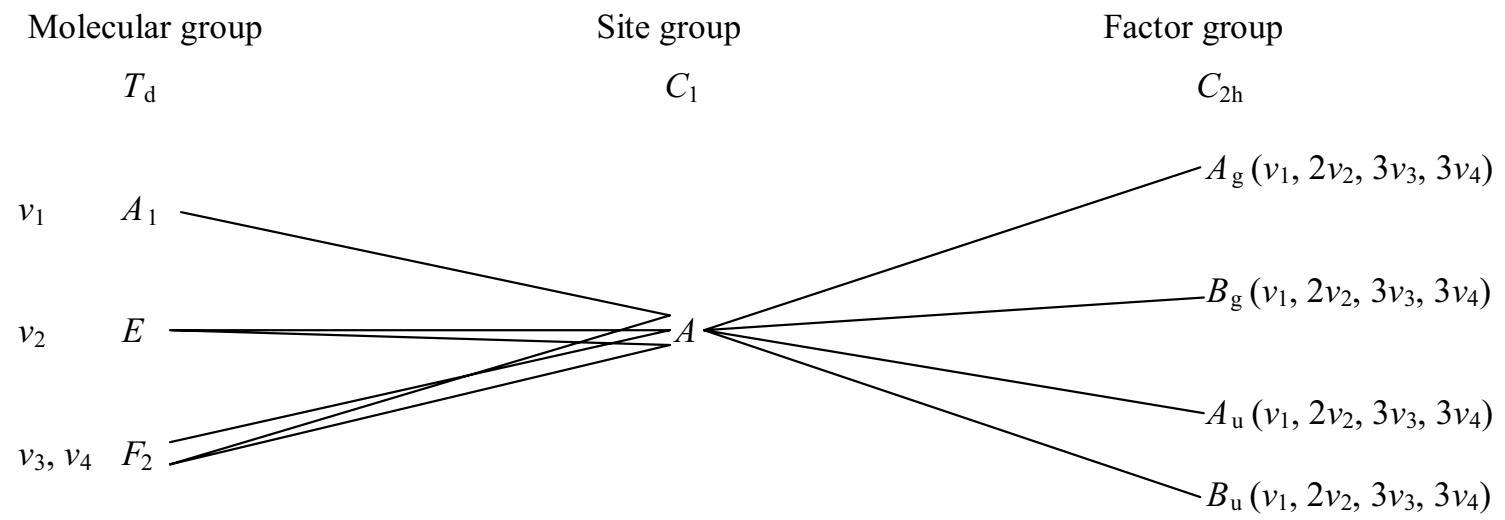

Fig. 4 Internal modes of sulfate ion in compound $\mathbf{1}$ 
Table 4 Sulfate ion internal vibrational modes and their assignation in the IR and Raman spectra of compound $\mathbf{1}$

\begin{tabular}{llllll}
\hline Species & Band & \multicolumn{2}{l}{ Measured $/ \mathrm{cm}^{-1}$} & Assignation \\
\cline { 3 - 5 } & & IR [34] & IR (our results) & $\begin{array}{l}\text { Raman }(785 \mathrm{~nm} \\
\text { excitation) }\end{array}$ \\
\hline$A_{1}$ & $\nu_{1}$ & 981 & 971 & 976 & $\nu_{\mathrm{S}}(\mathrm{S}-\mathrm{O})$ \\
$E$ & $\nu_{2}$ & - & 483 & 473 & $\delta_{\mathrm{S}}(\mathrm{S}-\mathrm{O})$ \\
$F_{2}$ & $\nu_{3}$ & 1079,1118 & $1037,1058,1105$ & $1022 *, 1101$ & $\nu_{\text {as }}(\mathrm{S}-\mathrm{O})$ \\
& $\nu_{4}$ & - & 611 & 617 & $\delta_{\text {as }}(\mathrm{S}-\mathrm{O})$ \\
\hline
\end{tabular}

band system centered at $1105 \mathrm{~cm}^{-1}$ (IR) with two shoulders (triplet nature) belongs to the antisymmetric S-O stretching mode, and according to this, a weak intensity band system could be observed $\left(\sim 1022\right.$ and $\left.\sim 1101 \mathrm{~cm}^{-1}\right)$ in the Raman spectrum. The double degenerate symmetric OSO bending mode of sulfate ion can be assigned around $483 \mathrm{~cm}^{-1}$ (IR) and $473 \mathrm{~cm}^{-1}$ (Raman). This band is also much more intensive in the Raman than in the IR spectrum.

\section{Vibrational modes of the crystallization waters}

Vibrational modes of $\mathrm{H}_{2} \mathrm{O}$ molecules under $C_{2 \mathrm{v}}$ symmetry are $\nu_{1}$ is the symmetric stretching vibration $\left(\nu_{\mathrm{s}}\right), \nu_{2}$ is the symmetric bending $\left(\delta_{\mathrm{s}}\right)$, and $\nu_{3}$ is the antisymmetric stretching vibration $\left(\nu_{\mathrm{as}}\right)$. The total number of factor group modes due to the internal vibrations of water is 12 . For three crystallographic types of water molecules that is equal to 36 vibrational degrees of freedom, external modes of $\mathrm{H}_{2} \mathrm{O}$ molecules under $C_{2 \mathrm{v}}$ symmetry: $R_{\mathrm{z}}=\tau ; R_{\mathrm{x}}=\omega ; R_{\mathrm{y}}=\rho$. The total number of factor group modes due to the external vibrations of water is 24 . For three crystallographic types of water molecules that equals 72 external degrees of freedom (36 hindered rotations and 36 hindered translations) (ESI Fig. 1), the degeneracies are lifted and all the internal and external mode bands are IR and Raman active. Both stretching modes of crystalline water are located in the higher wavenumber side of the band positions of NH stretching modes and appear around $3500 \mathrm{~cm}^{-1}$ as a shoulder. The bands of symmetric bending mode of water are expected to be located between 1600 and $1640 \mathrm{~cm}^{-1}$. However, in this range, there is a complex band system which contains not only the six types of symmetric $\mathrm{OH}_{2}$ deformation band (scissoring mode) but also the bands belong to the stretching mode of the non-coordinated $\mathrm{C}=\mathrm{O}$ bonds of two kinds of carbonate ion and the eight kinds of an antisymmetric deformation mode of coordinated ammonia. The Raman spectra recorded with $532 \mathrm{~nm}$ excitation contains a complicated band system centered at $3495 \mathrm{~cm}^{-1}$ and assigned to the symmetric and antisymmetric stretching modes of crystalline water molecules in compound $\mathbf{1}$. One should expect a great extent of mode mixing as a result of the lowest possible symmetry of all units. A possible way to offer a more reasonable assignment (backed by experiment) would be to prepare isotopically substituted samples, where $\mathrm{D}_{2} \mathrm{O}$ substitutes water molecules. Water librations (hindered rotations) are expected to be highly affected by the H/D replacement (for pure modes, isotopic ratios close to 1.35 are expected) [39].

\section{Lattice vibrations and combination bands}

Over the assigned bands belonging to the cis- $\mathrm{O}_{2} \mathrm{CoN}_{4}$ skeleton, some lattice vibrations could also be found in the farIR spectra at 56, 60, 76 and $96 \mathrm{~cm}^{-1}$. The Raman spectra recorded at 532 and $785 \mathrm{~nm}$ contains a weak lattice vibration at $114 \mathrm{~cm}^{-1}$ (ESI Figs. 3 and 4), while in the far-IR spectra (ESI Fig. 5), a wide shoulder system can be seen around this wavenumber value.

There is a multiple very wide band system located between 1700 and $2700 \mathrm{~cm}^{-1}$ and consists of overtones and combination bands of the species built the compound 1 . The appearance of $2 \nu_{2}$ overtone (2082 and 1985) and $\nu_{1}+\nu_{3}$ combination (2385 and $2347 \mathrm{~cm}^{-1}$ ) for carbonate ion, or $\nu_{1}+\nu_{3}(\mathrm{c})$ component overtone of sulfate ion $\left(2082 \mathrm{~cm}^{-1}\right)$ might be present in this band system, where $c$ means the highest wavenumber component of the triply degenerate sulfate antisymmetric stretching mode [39].

\section{UV spectra of compound 1}

The carbonatoammine complexes of cobalt are low-spin complexes with $d^{6}\left(t_{2 \mathrm{~g}}^{6}\right)$ electron configuration and an electron excitation into the $e_{\mathrm{g}}$, orbital leads to $t_{2 \mathrm{~g}}^{5} e_{\mathrm{g}}$ configuration. The low-spin ground state in an octahedral field is ${ }^{1} A_{1 \mathrm{~g}}$. Twospin-allowed to singlet $\left({ }^{1} T_{1 \mathrm{~g}}\right.$ and $\left.{ }^{1} T_{2 \mathrm{~g}}\right)$ and two-spin-forbidden transitions to triplet states $\left({ }^{3} T_{1 \mathrm{~g}}\right.$ and $\left.{ }^{3} T_{2 \mathrm{~g}}\right)$ are possible when the triplet states lie at lower energy than the singlet ones. The UV-Vis spectrum of compound $\mathbf{1}$ can be seen in ESI Fig. 6 and Table 5.

The purplish color of the compound $\mathbf{1}$ is related to the strongest spin-allowed transition $\left({ }^{1} T_{1 \mathrm{~g}} \leftarrow{ }^{1} A_{1 \mathrm{~g}}\right)$ at $537 \mathrm{~nm}$. The second principal band belongs to the other spin-allowed transition $\left({ }^{1} T_{2 \mathrm{~g}} \leftarrow{ }^{1} A_{1 \mathrm{~g}}\right)$, while the two spin-forbidden transitions $\left({ }^{3} T_{1 \mathrm{~g}} \leftarrow{ }^{1} A_{1 \mathrm{~g}}\right.$ and $\left.{ }^{3} T_{2 \mathrm{~g}} \leftarrow{ }^{1} A_{1 \mathrm{~g}}\right)$ resulted in weak bands. The wavenumbers of these bands are sensitive to distortion of the octahedral symmetry, due to the hydrogen bonds influence on the shifting from the theoretically found 
Fig. 5 TG-DTG curve of compound 1 in air and $\mathrm{N}_{2}$ atmosphere

Fig. 6 DSC curves of compound $\mathbf{1}$ in air and $\mathrm{N}_{2}$
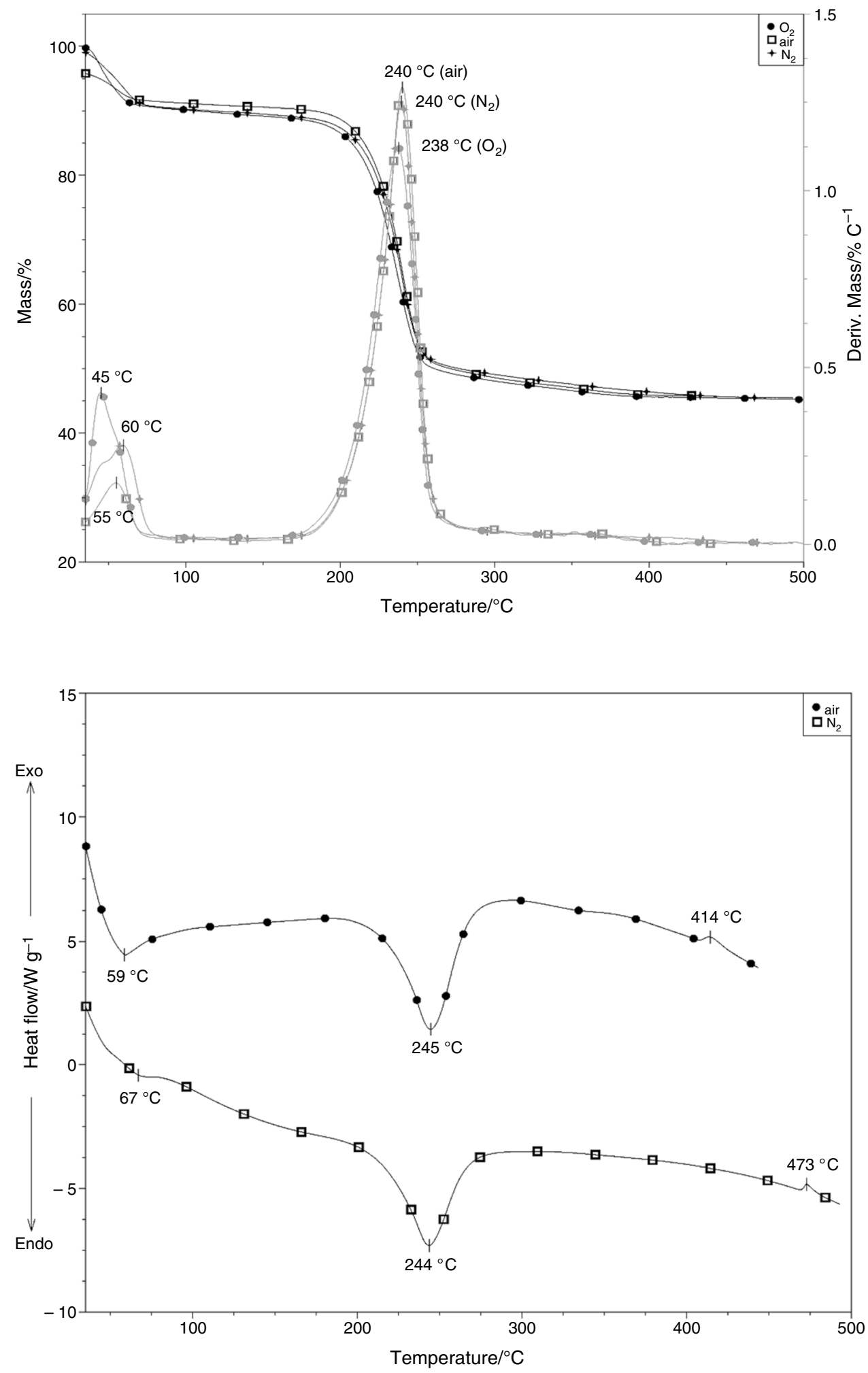

values calculated by Sastri and Langford [41]. A CT band at $300 \mathrm{~nm}$ was assigned as an $L_{\pi} \rightarrow \operatorname{Co}\left(e_{\mathrm{g}}\right)$-type ligand-tometal-type (LMCT) electron transfer and confirms that the carbonate ion has more than $50 \%$ covalency in compound 1 [42].

\section{Thermal studies on compound 1}

The thermal decomposition processes of $\left[\mathrm{CoCO}_{3}\left(\mathrm{NH}_{3}\right)_{4}\right]$ $\mathrm{SO}_{4} \cdot 3 \mathrm{H}_{2} \mathrm{O}$ (compound $\mathbf{1}$ ) have been studied since the late 1970s of the last century $[21,22]$. The controversies in the 
Table 5 Experimental UV-Vis data for compound 1 and calculated ones for the $\left[\mathrm{Co}\left(\mathrm{NH}_{3}\right)_{4} \mathrm{CO}_{3}\right]^{+}$ion

\begin{tabular}{llll}
\hline Assignment & \multicolumn{2}{l}{$\nu_{\max } / \mathrm{cm}^{-1}(\mathrm{~nm})$} & \\
\cline { 2 - 4 } & Compound 1, & Compound 2 & $\begin{array}{l}{\left[\mathrm{Co}(\mathrm{NH} 3)_{4} \mathrm{CO}_{3}\right]^{+}} \\
\text {ion }[41]\end{array}$ \\
\hline${ }^{1} \mathrm{~T}_{1 \mathrm{~g}} \leftarrow{ }^{1} \mathrm{~A}_{1 \mathrm{~g}}$ & $18,622(537)$ & $18,621(537)$ & $19,280(519)$ \\
${ }^{1} \mathrm{~T}_{2 \mathrm{~g}} \leftarrow{ }^{1} \mathrm{~A}_{1 \mathrm{~g}}$ & $26,316(380)$ & $26,809(373)$ & $27,200(368)$ \\
${ }^{3} \mathrm{~T}_{1 \mathrm{~g}} \leftarrow{ }^{1} \mathrm{~A}_{1 \mathrm{~g}}$ & $11,990(834)$ & - & $11,840(845)$ \\
${ }^{3} \mathrm{~T}_{2 \mathrm{~g}} \leftarrow{ }^{1} \mathrm{~A}_{1 \mathrm{~g}}$ & $15,314(653)$ & - & $15,800(633)$ \\
$\mathrm{LMCT} \pi-e_{\mathrm{g}}$ & $33,333(300) \mathrm{sh}$ & $33,444(299)$ & - \\
\hline
\end{tabular}

results found in inert atmosphere and air make it highly desirable to prove the decomposition mechanism by modern, sophisticated techniques. Therefore, compound $\mathbf{1}$ was analyzed by simultaneous TG-DSC and coupled TG-MS measurements in both inert and oxidative atmosphere until $500{ }^{\circ} \mathrm{C}$. The crystal hydrate $\left[\mathrm{CoCO}_{3}\left(\mathrm{NH}_{3}\right)_{4}\right] \mathrm{SO}_{4} \cdot 3 \mathrm{H}_{2} \mathrm{O}$ begins to lose its lattice water at about room temperature in both nitrogen and air (Fig. 5). This step is completed up to about $90{ }^{\circ} \mathrm{C}$. Our results show that dehydration occurs at a significantly lower temperature (from r.t. to $\sim 90{ }^{\circ} \mathrm{C}$ ) than the published ones by Amigo [21] and Onodera [22] (from 100 to $\sim 190{ }^{\circ} \mathrm{C}$ ). The dehydration process of complex $\mathbf{1}$ occurs in two overlapped steps, as seen from the DTG and DSC curves (Fig. 6). The peak temperature of water loss agrees with the result of Macikenas et al. $\left(T=59{ }^{\circ} \mathrm{C}\right)$, who confirmed the structure (identity) of their sample by single-crystal X-ray diffraction. The somewhat lower mass percent values $(9.7 \%$ in $\mathrm{N}_{2}$ and $\sim 9.0 \%$ in air) than the calculated for three water molecules (theoretical value is $10.31 \%$ ) are also in accordance with spontaneous water lose even at room temperature.

By water loss, anhydrous $\left[\mathrm{CoCO}_{3}\left(\mathrm{NH}_{3}\right)_{4}\right] \mathrm{SO}_{4}$ (compound 2) was formed, stable up to $221{ }^{\circ} \mathrm{C}$ onset, as it was found at isotherm heating of compound $\mathbf{1}$ at $120^{\circ} \mathrm{C}$ in air [21]. There are no significant differences between the decomposition mechanism of compound $\mathbf{1}$ in inert and oxidative atmosphere up to $500{ }^{\circ} \mathrm{C}$. In other words, environmental oxygen does not affect the decomposition features in this temperature range. To examine the effect of environmental oxygen on decomposition mechanism at higher temperatures and the final product, compound $\mathbf{1}$ was heated in both $\mathrm{N}_{2}$ and air atmosphere isothermally at $800{ }^{\circ} \mathrm{C}$ for $2 \mathrm{~h}$.

Both Amigo and Onodera found ammonia and carbon dioxide evolution around $240{ }^{\circ} \mathrm{C}[21,22]$, in one step, but only Onodera could detect $\mathrm{N}_{2}$ as an oxidation product of ammonia. We found $45.6 \%$ and $44.7 \%$ of mass loss in air and $\mathrm{N}_{2}$, respectively, which is somewhat more than the theoretical value (\%). The reaction heat was found to be $437.49 \mathrm{~kJ} \mathrm{~mol}^{-1}$ and $507.18 \mathrm{~kJ} \mathrm{~mol}^{-1}$ in air and $\mathrm{N}_{2}$ atmosphere, respectively (DSC). These are consistent with formation of some residual ammonium sulfate detected by
Onodera [22] and confirmed by us with IR studies on the decomposition intermediates formed at $300{ }^{\circ} \mathrm{C}$. The difference in amount of ammonium sulfate in air and $\mathrm{N}_{2}$ causes some minor alteration in the measured reaction heats (Fig. 6). Decomposition intermediates to study the presence and absence of ammonium sulfate intermediate were made at $300{ }^{\circ} \mathrm{C}$ in both $\mathrm{N}_{2}$ and air atmosphere with and without prolonged heating. This intermediate was proved to be $\mathrm{X}$-ray amorphous. The IR spectrum contained the characteristic bands of ammonium ions $\left(\delta_{\mathrm{as}}=1433 \mathrm{~cm}^{-1}, \delta_{\mathrm{s}}=1632 \mathrm{~cm}^{-1}\right.$, $\nu_{1}, \nu_{3} 3397$ and $3263 \mathrm{~cm}^{-1}$, respectively, $\nu_{1}+\nu_{5}$ at $3515 \mathrm{~cm}^{-1}, \nu_{2}+\nu_{4}$ at $3178 \mathrm{~cm}^{-1}, \nu_{4}+\nu_{6}=1713 \mathrm{~cm}^{-1}$ and $2 \nu_{4} 2916 \mathrm{~cm}^{-1}$ [43]) and strong sulfate bands $\left(\nu_{1}=982 \mathrm{~cm}^{-1}\right.$ (A), $\nu_{2}=486 \mathrm{~cm}^{-1}(E), \nu_{3}=1118,1063 \mathrm{~cm}^{-1}$ (F2) $\nu_{4}=657,622,593 \mathrm{~cm}^{-1}$ (F2)) [39]. It has to be mentioned that small peaks of carbonate ion (substitutes the sulfate in the cobalt salts) may also observed at 833 and $1530 \mathrm{~cm}^{-1}$. The appearance of combination and overtone bands of ammonium ion might be attributed to the hindered rotation of ammonium ion as found in strong hydrogen-bond systems like $\left(\mathrm{NH}_{4}\right)_{2} \mathrm{SO}_{4}[43,44]$ (ESI Fig. 7). The bands of ammonium sulfate disappeared on prolonged heating $(>2 \mathrm{~h})$. It is very probably that ammonium sulfate decomposes thermally and reacts with carbonate residues which causes deficit in $\mathrm{Co} /$ sulfate ratio and appearing excess of oxide as counter ion. The incompleteness of the cobalt(III) reduction in the main reaction steps $\left(\sim 240{ }^{\circ} \mathrm{C}\right)$ results in residual $\mathrm{Co}$ (III) content in the samples heated in air or inert atmosphere at $300{ }^{\circ} \mathrm{C} \mathrm{(5.3} \mathrm{and} 2.8 \%$ in air and $\mathrm{N}_{2}$, respectively). The formula of compound $\mathbf{3}$ formed under oxidative (3a) and inert (3b) conditions at $300{ }^{\circ} \mathrm{C}$ was determined. In both cases, a kind of basic cobalt(II) sulfate was formed. The exact composition of the phases was found to be $\mathrm{Co}_{2} \mathrm{O}_{1,25+\delta}\left(\mathrm{SO}_{4}\right)_{0.75}$ ( $\delta=$ the oxygen surplus due to presence of $5.3 \%$ of $\mathrm{Co}$ (III) ion (compound 3a) and $\mathrm{Co}_{2} \mathrm{O}_{1,14+\delta}\left(\mathrm{SO}_{4}\right)_{0.86}(\delta=$ the oxygen surplus due to presence of $2.8 \%$ of $\mathrm{Co}(\mathrm{III})$ ion (compound 3b). It unambiguously showed the presence of a cobalt(III) reduction into cobalt(II) in aerial environment as well.

Compound 3a is oxidized at $719{ }^{\circ} \mathrm{C}$ and forms $\mathrm{Co}_{3} \mathrm{O}_{4}$. We could not detect complete oxidation of cobalt(II) in compound 3 to form cobaltyl sulfate $\left.(\mathrm{CoO})_{2} \mathrm{SO}_{4}\right)$. As can be seen, besides the dehydration, the decomposition process is also endothermic independently of the atmosphere. However, the transformation of the unidentified minor intermediate is exothermic both in air and inert atmosphere. The small exothermic peaks were found at $\sim 416{ }^{\circ} \mathrm{C}$ in air and $\sim 473{ }^{\circ} \mathrm{C}$ in inert atmosphere. Mass change at these temperatures was practically not detectable. The differences might be attributed to the behavior of the minor unidentified intermediate toward oxygen and some other solid components in compound 3a in the lack of oxygen. Due to different behavior of this intermediate component in air and $\mathrm{N}_{2}$, to identify the possible role of oxygen/the lack of oxygen in these 
Fig. 7 Thermal decomposition of compound $\mathbf{1}$ in the presence of oxygen

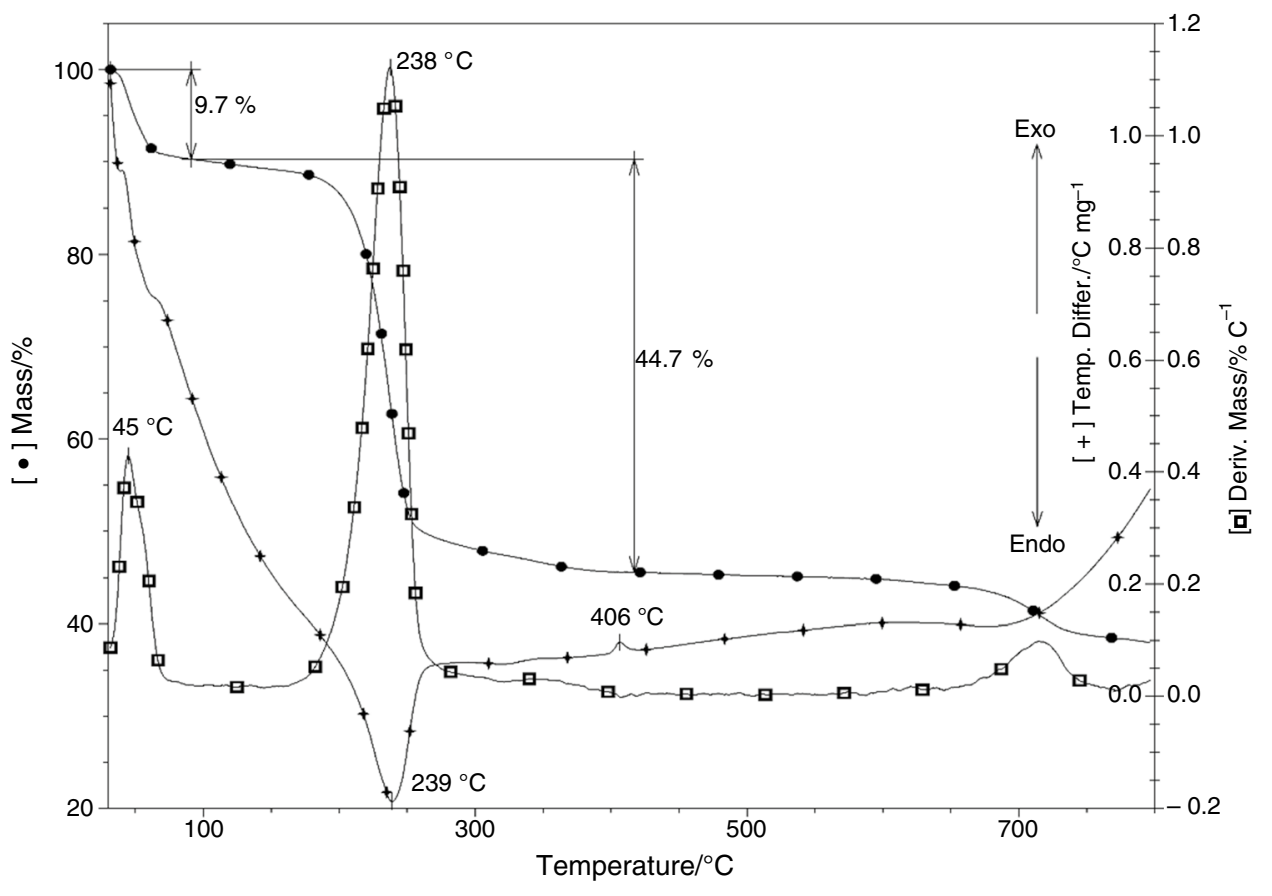

exothermic processes, a TG-DSC experiment in the presence of $\mathrm{O}_{2}$ was performed until $800{ }^{\circ} \mathrm{C}$ (Fig. 7).

The end product of decomposition was found to be $\mathrm{Co}_{3} \mathrm{O}_{4}$ in air, as stated by Amigo et al. [21]. However, in an inert atmosphere, a mixture of $\mathrm{CoO}$ and two allotropes (hcp and fcc cobalt) of metallic cobalt could be found in ca. 40:35:25 ratio (Fig. 8). The measurement has been repeatedly taken a high-temperature XRD as well when $\mathrm{Al}_{2} \mathrm{O}_{3}$ as a reference material was used to avoid the shifting in the diffractogram caused by the thermal expansion and phase transformation. Surprisingly, in this case, only crystalline $\mathrm{CoO}$ could be detected even at $800{ }^{\circ} \mathrm{C}$ or room temperature.

The metallic cobalt formed in the redox decomposition step $\sim 240{ }^{\circ} \mathrm{C}$ as one of the redox products. The hcp-Co:fcc$\mathrm{Co}: \mathrm{CoO}$ ratio was found to be 25:35:40. Oxidation of nanosize cobalt particles in air or $\mathrm{O}_{2}$ into $\mathrm{CoO} / \mathrm{Co}_{3} \mathrm{O}_{4}$ might initiate the exoeffect at $415{ }^{\circ} \mathrm{C}$. The cobalt oxidation temperature strongly depends on the size of cobalt particles and might be from room temperature until the temperature of red hot. In inert atmosphere, the lack of oxygen discloses this process and according to this, there is no exoeffect on the DSC curve at this temperature. The hexagonal-cubic phase transition temperature ( $h c p-f c c, 450-490^{\circ} \mathrm{C}$, its temperature strongly depends on impurity and grain size [45] of cobalt) coincides with the temperature of the exoeffect observed in inert atmosphere $\left(473{ }^{\circ} \mathrm{C}\right)$, but the phase transition should be endothermic. Thus, this peak is attributed to the reaction of reactive nanosize cobalt (15 and $250 \mathrm{~nm}$ for hcp-Co and fcc-Co, respectively) particles with other components like $\mathrm{CoO}$ or $\mathrm{Co}_{2} \mathrm{OSO}_{4}$.
To examine the decomposition mechanism and the redox processes in inert and oxidative atmosphere, the evolved gases were analyzed by coupled TG-MS measurements (Figs. 9 and 10). Water evolution was found during the dehydration and the main decomposition steps. The appearance of water during the decomposition of the anhydrous $\left[\mathrm{Co}\left(\mathrm{NH}_{3}\right)_{4} \mathrm{CO}_{3}\right]_{2} \mathrm{SO}_{4}$ confirms the existence of a redox reaction involving the ammonia. The only hydrogen source for water formation might be the ammonia. The water $\left(m / z=18,17,16\left(\mathrm{H}_{2} \mathrm{O}^{+}, \mathrm{HO}^{+}\right.\right.$and $\left.\mathrm{O}^{+}\right)$and ammonia curves $\left(m / z=17,16,15,14\left(\mathrm{NH}_{3}^{+}, \mathrm{NH}_{2}^{+}, \mathrm{NH}^{+}\right.\right.$and $\left.\left.\mathrm{N}^{+}\right)\right)$cannot be distinguished in the case of $\mathrm{m} / \mathrm{z}=17$ and 16 . However, the $m / z=18$ peaks may belong only to water and the $m / z=15$ or 14 may not belong to the water, but their source might be other nitrogen-containing parent ions as $\mathrm{N}_{2}^{+}$or $\mathrm{N}_{2} \mathrm{O}^{+}$. The $m / z=15$ might also be double ionized $\mathrm{N}_{2} \mathrm{O}\left(\mathrm{N}_{2} \mathrm{O}^{2+}\right.$, $m / z=30 / 2)$ ). We could not confirm Onodera [22] result about multistep ammonia losing and formation of a $\mathrm{Co}$ (III)containing intermediate, $\left(\left[\mathrm{Co}\left(\mathrm{NH}_{3}\right)_{3} \mathrm{CO}_{3}\right]_{2} \mathrm{SO}_{4}\right.$, compound 4 ) at $200{ }^{\circ} \mathrm{C}$. However, the $\mathrm{N}_{2}$ as a product of the redox reaction is verified by the appearance of $m / z=28$ peak. Indeed, the $\mathrm{CO}_{2}$ fragmentation formed by ligand loss also results in $\mathrm{CO}^{+}$as a fragment peak with the same $\mathrm{m} / z$ value. The situation is more complicated because the parent of $\mathrm{CO}^{+}$is $\mathrm{CO}_{2}$, a typical carbonate decomposition product $(\mathrm{m} / \mathrm{z}=44)$ and a possible ammonia oxidation product $\left(\mathrm{N}_{2} \mathrm{O}\right)$ [46] have peak at this $\mathrm{m} / z$ value, and its possible fragments are $\mathrm{NO}^{+}$ $(m / z=30)$ or $\mathrm{N}_{2}^{+}(m / z=28)$.

Comparing the relative intensities of parent and their fragment ions for the $\mathrm{H}_{2} \mathrm{O} / \mathrm{NH}_{3}$ and $\mathrm{CO}_{2} / \mathrm{CO}$ or $\mathrm{N}_{2} \mathrm{O} / \mathrm{N}_{2} /$ NO systems [47], it can roughly estimate the contribution of 

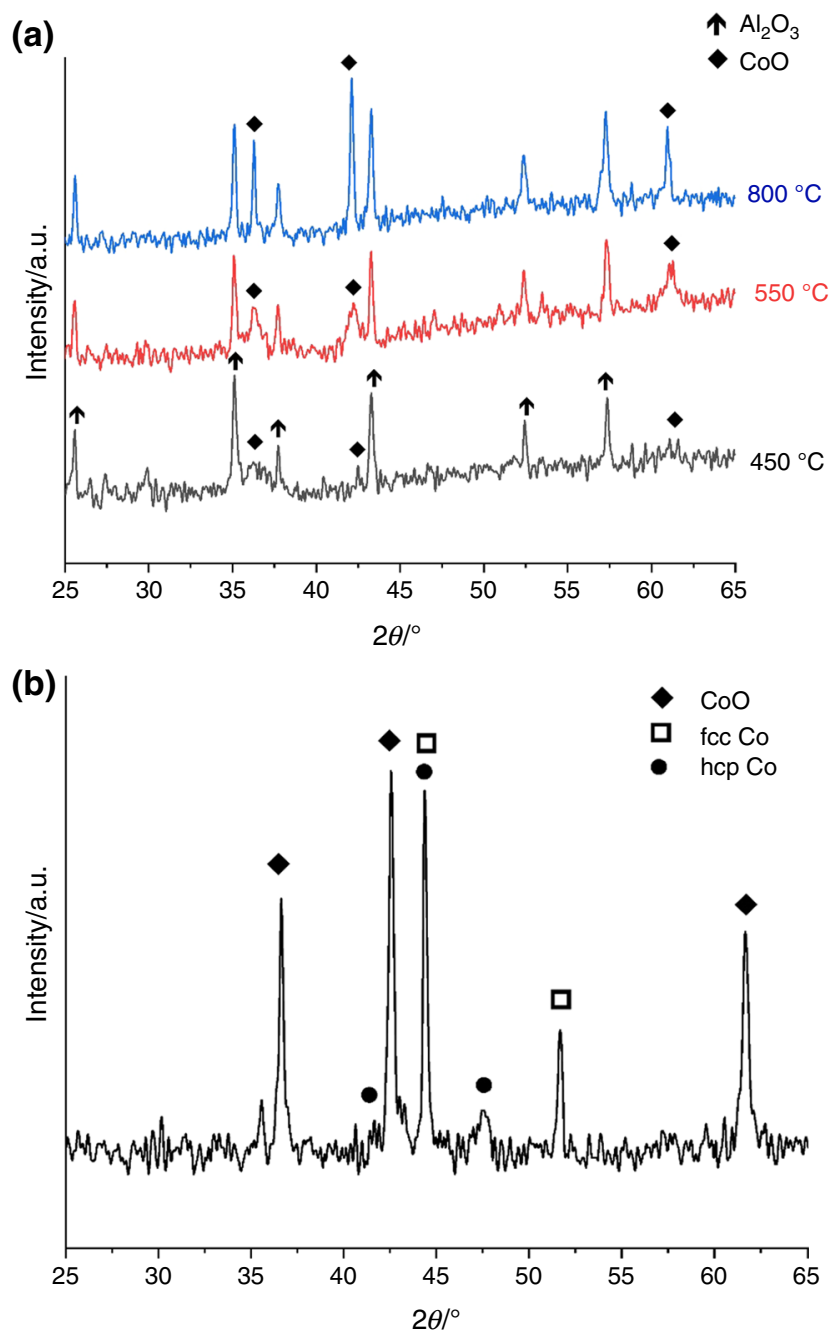

Fig. 8 High-temperature XRD of the decomposition product of compound 1 in inert atmosphere measured at 450,550 and $800{ }^{\circ} \mathrm{C}$ in the presence of $\mathrm{Al}_{2} \mathrm{O}_{3}$ a and $\mathrm{XRD}$ of the decomposition product heat treated isothermally in inert atmosphere at $800{ }^{\circ} \mathrm{C} \mathrm{b}$

each fragmentation process to the intensities of the appeared fragment ions. For example, the high intensity of $m / z=17$ comparing with $m / z=18$ shows that the main component of $m / z=17$ is the ammonia. A smaller contribution can be expected from the water fragmentation $\left(m / z=17, \mathrm{OH}^{+}\right)$ because the intensity ratio of $m / z=18$ and $m / z=17$ is $\sim 4: 1$ in the case of water only.

Based on this, the intensity contribution of $\mathrm{NH}_{3}$ fragments $\left(\mathrm{NH}_{2}\right)$ and oxygen from the water $(\mathrm{O})$ can also be estimated, because the contribution of ammonia to this peak is ca. $80 \%$ related to the $m / z=17\left(\mathrm{NH}_{3}\right)$. In comparison, in the case of water, it is negligible ( $1 \%$ comparing with $m / z=18$ intensity). The $m / z=16$ peak may be due to any other oxygen-containing gases like $\mathrm{CO}_{2}$ or $\mathrm{NO}_{\mathrm{x}}$ compounds.

The $\mathrm{N}_{2} \mathrm{O}$ is a possible decomposition product of transition metal ammonia complexes with oxidizing ligands [1-3,
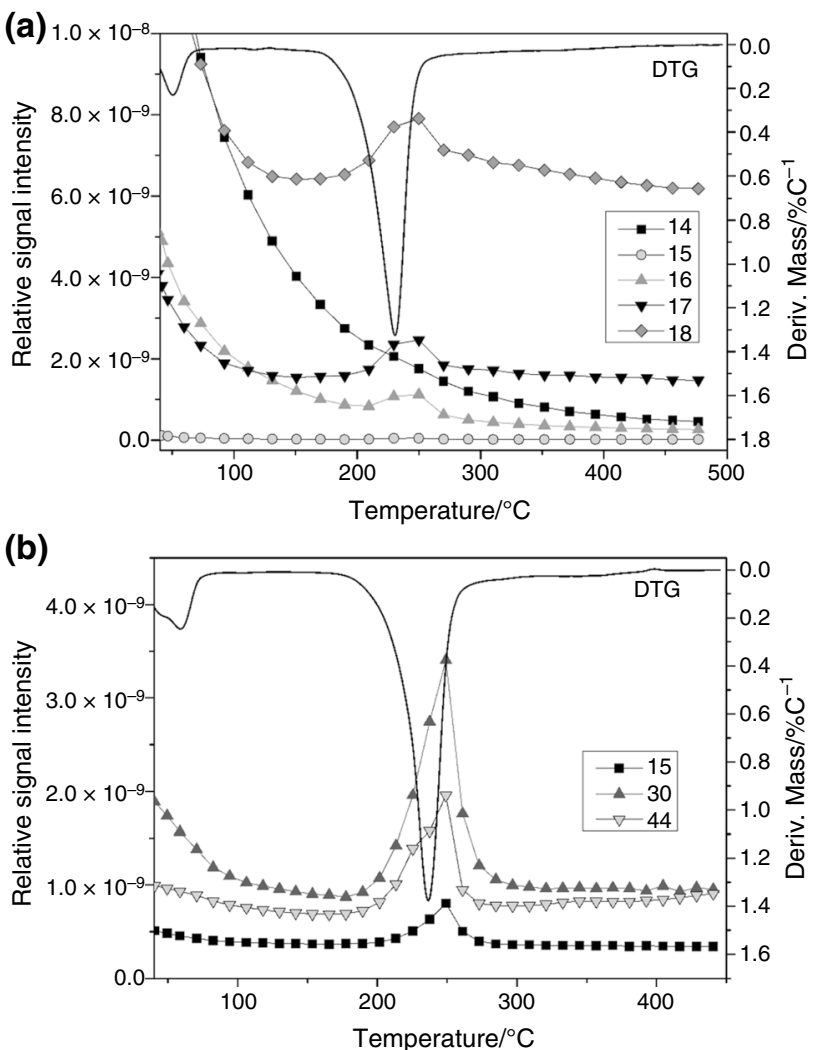

Fig. 9 TG-MS curves of compound 1 under argon atmosphere

$46,48]$. Unfortunately, it gives a peak on $m / z=44$ like $\mathrm{CO}_{2}^{+}$. Their main fragments $\left(\mathrm{CO}^{+}\right.$or $\mathrm{N}_{2}^{+}$, respectively) also have the same $m / z=28$; therefore, they cannot be distinguished. However, $\mathrm{NO}^{+}$, as a fragmentation product of $\mathrm{N}_{2} \mathrm{O}^{+}$, appears in the case of $\mathrm{N}_{2} \mathrm{O}$ only. But $\mathrm{NO}$ may also be a direct oxidation product of ammonia $[1-3,46]$. Since the intensity value of $m / z=44$ is comparable but smaller than the intensity of $m / z=30\left(\mathrm{NO}^{+}\right)$, despite $\mathrm{CO}_{2}^{+}$contribution to the $\mathrm{m} / z=44$ peak, it suggests that $\mathrm{NO}^{+}$is not a fragmentation product of $\mathrm{N}_{2} \mathrm{O}^{+}$but a direct oxidation product of ammonia. The decomposition character of compound $\mathbf{1}$ in air confirmed that the same processes play a role in both atmospheres in the decomposition of $\mathbf{1}$ until $300{ }^{\circ} \mathrm{C}$.

Summarizing the results of TG, DTG and TG-MS studies, combining with the IR and XRD results of intermediates and final decomposition products, the main thermal decomposition reactions of compound $\mathbf{1}$ are the following.

(a) $\left[\mathrm{Co}\left(\mathrm{NH}_{3}\right)_{4} \mathrm{CO}_{3}\right]_{2} \mathrm{SO}_{4} \cdot 3 \mathrm{H}_{2} \mathrm{O}=3\left[\mathrm{Co}\left(\mathrm{NH}_{3}\right)_{4} \mathrm{CO}_{3}\right]_{2} \mathrm{SO}_{4}+3 \mathrm{H}_{2} \mathrm{O}$

The reaction is reversible, endothermic, and the anhydrous salt has the same coordination sphere as the starting compound 1 . The reaction proceeds between 40 and $60^{\circ} \mathrm{C}$.

The main decomposition reaction is an endothermic redox reaction between the ammonia ligands and cobalt(III) cation 
[49], both in an inert atmosphere and in air. The redox products are basic cobalt(II) sulfates, elementary nitrogen and water. Other products are carbon dioxide and ammonia. These are evolved together, but the decomposition probably starts with the ammonia oxidation process in the solid phase. A small amount of ammonium sulfate could be detected. However, the presence of ammonium nitrate as an oxidation product and $\mathrm{N}_{2} \mathrm{O}$ precursor could not be verified by FTIR measurement, because the nitrate bands coincide with the $\mathrm{NH}_{4}^{+}$bands around $1400 \mathrm{~cm}^{-1}$, and the $\mathrm{N}_{2} \mathrm{O}^{+}$main peaks coincide with the $\mathrm{CO}_{2}^{+}$ and $\mathrm{CO}^{+}$fragment peaks formed from the leaving carbonate group. A minor amount of $\mathrm{SO}^{+}(\mathrm{m} / \mathrm{z}=48)$ fragment could be detected from the $\mathrm{SO}_{2} / \mathrm{SO}_{3}$ parents [47]. It can cause the deficiency in sulfate/Co ratio $(<1: 2)$ attributed to the ammonium sulfate gradual decomposes on prolonged isotherm heating or with increasing the decomposition temperature. Another ammonia oxidation product, $\mathrm{NO}$, is also verified.

(b) $3\left[\mathrm{Co}\left(\mathrm{NH}_{3}\right)_{4} \mathrm{CO}_{3}\right]_{2} \mathrm{SO}_{4}=6 \mathrm{CoCO}_{3}+\mathrm{N}_{2}+3\left(\mathrm{NH}_{4}\right)_{2} \mathrm{SO}_{4}+16 \mathrm{NH}_{3}$ $\frac{6 \mathrm{CoCO}_{3}+3\left(\mathrm{NH}_{4}\right)_{2} \mathrm{SO}_{4}=3 \mathrm{Co} 2 \mathrm{OSO}_{4}+6 \mathrm{NH}_{3}+6 \mathrm{CO}_{2}+3 \mathrm{H}_{2} \mathrm{O}}{3\left[\mathrm{Co}\left(\mathrm{NH}_{3}\right)_{4} \mathrm{CO}_{3} \mathrm{SO}_{4}+3 \mathrm{Co}_{2} \mathrm{OSO}_{4}+22 \mathrm{NH}_{3}+\mathrm{N}_{2}+6 \mathrm{CO}_{2}+3 \mathrm{H}_{2} \mathrm{O}\right.}$ $3\left[\mathrm{Co}\left(\mathrm{NH}_{3}\right)_{4} \mathrm{CO}_{3}\right]_{2} \mathrm{SO}_{4}+3 \mathrm{Co}_{2} \mathrm{OSO}_{4}+22 \mathrm{NH}_{3}+\mathrm{N}_{2}+6 \mathrm{CO}_{2}+3 \mathrm{H}_{2} \mathrm{O}$
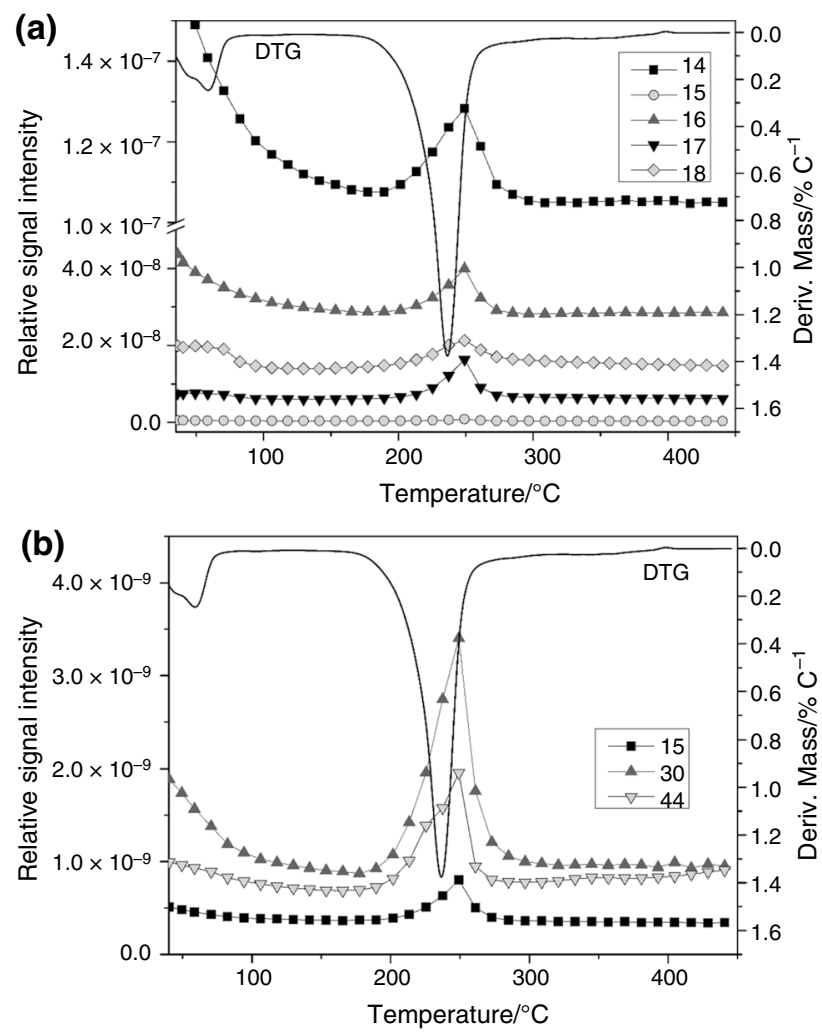

Fig. 10 TG-MS curves of decomposition products and their fragments on heating of compound $\mathbf{1}$ in air
The basic cobalt sulfate, $\mathrm{Co}_{2} \mathrm{OSO}_{4}$, decomposes with the formation of $\mathrm{CoO}$ in an inert atmosphere but is oxidized into $\mathrm{Co}^{\mathrm{II}} \mathrm{Co}_{2}^{\mathrm{III}} \mathrm{O}_{4}\left(\mathrm{Co}_{3} \mathrm{O}_{4}\right)$ in the air at $917^{\circ} \mathrm{C}$.

(c)

$$
\begin{aligned}
& \text { (c) } \mathrm{Co}_{2} \mathrm{OSO}_{4}=2 \mathrm{CoO}+\mathrm{SO}_{2}+0.5 \mathrm{O}_{2} \\
& \text { (d) } 3 \mathrm{Co}_{2} \mathrm{OSO}_{4}=2 \mathrm{Co}_{3} \mathrm{O}_{4}+3 \mathrm{SO}_{2}+0.5 \mathrm{O}_{2}
\end{aligned}
$$

(inert atmosphere)

(in air atmosphere).

\section{Characterization of compound 2}

The compound $\mathbf{2}$ was prepared by thermal dehydration of compound 1 at $120^{\circ} \mathrm{C}$. The bands belonging to the cationic skeletal and ligand vibrations (ammonia and carbonate) could be assigned comparing the measured data with the results given for compound $\mathbf{1}$ (ESI Fig. 8). The bands belonging to crystallization water have disappeared. Numerous bands are overlapped with each other, e.g., $\delta_{\mathrm{s}}(\mathrm{NH})$ and $\nu(\mathrm{C}=\mathrm{O})$ stretching between 1650 and $1600 \mathrm{~cm}^{-1}$, and the antisymmetric and the symmetric $\mathrm{C}-\mathrm{O}$ stretchings of carbonate ion are overlapped by antisymmetric $\mathrm{S}-\mathrm{O}$ stretching observed at $1074 \mathrm{~cm}^{-1}$. The $\pi\left(\mathrm{CO}_{3}\right)$ is mixed with $\rho\left(\mathrm{NH}_{3}\right)$ at $833 \mathrm{~cm}^{-1}$. The $\nu \mathrm{CoN}(\mathrm{O})$ mode and the symmetric $\mathrm{S}-\mathrm{O}$ deformation are mixed around $477 \mathrm{~cm}^{-1}$. The presence of two bands at 1516 and $1429 \mathrm{~cm}^{-1}$ appears only in the spectrum of compound 2; thus, these bands show some special (hydrogen bonding) interactions of ligands involving water of crystallization.

The spin-allowed and CT bands of the cation could be found for compound $\mathbf{2}$. The slight shifts of the wavenumbers shows that dehydration has no significant influence on the coordination of the complex cation. The two forbidden transitions cannot be observed. The appearance of the separated CT band around $300 \mathrm{~nm}$ in the spectrum of compound 2 instead of a shoulder observed in the spectra of compound $\mathbf{1}$ shows that the strong band covered by the $\mathrm{CT}$ band belongs to the water or water-bound species $(\sim 250 \mathrm{~nm})$ (Water is bound by hydrogen bonds to sulfate [20] in compound 1.) The lattice parameters of compound $\mathbf{2}$ could not be determined by XRD due to insufficient crystallinity of the sample (ESI Fig. 9). The $d$ values are given in ESI Table 1. The morphology of the compound $\mathbf{2}$ was studied by SEM, and the result can be seen in Fig. 11. SEM images indicate the $\left[\mathrm{Co}\left(\mathrm{NH}_{3}\right)_{4} \mathrm{CO}_{3}\right] \mathrm{SO}_{4}$ has a rugged surface. As can be seen, the crystallites possess irregular planar shape and aggregated in several micrometer-size.

\section{Characterization of $\mathrm{CoO}_{1.25+\delta} \mathrm{Co}\left(\mathrm{SO}_{4}\right)_{0.75}$ and $\mathrm{CoO}_{1.12+\delta} \mathrm{Co}\left(\mathrm{SO}_{4}\right)_{0.88}$ basic cobalt sulfates}

The basic cobalt sulfates, $\mathrm{CoO}_{1.25+\delta} \mathrm{Co}\left(\mathrm{SO}_{4}\right)_{0.75}$ (compounds 3a) and $\mathrm{CoO}_{1.12+\delta} \mathrm{Co}\left(\mathrm{SO}_{4}\right)_{0.88}$ (compound $3 \mathbf{b}$ ) were prepared as pink powders by heating of compound $\mathbf{1}$ at $300 \mathrm{C}^{\circ}$ for $2.5 \mathrm{~h}$ in air or $\mathrm{N}_{2}$ atmosphere for $2 \mathrm{~h}$. Compounds $3 \mathrm{a}$ and 3b contain less sulfate ion than it was expected from the 


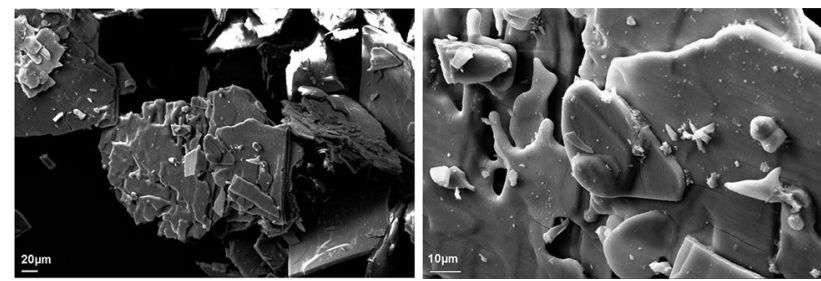

Fig. $11 \mathrm{SEM}$ picture of $\left[\mathrm{Co}\left(\mathrm{NH}_{3}\right)_{4} \mathrm{CO}_{3}\right] \mathrm{SO}_{4}$

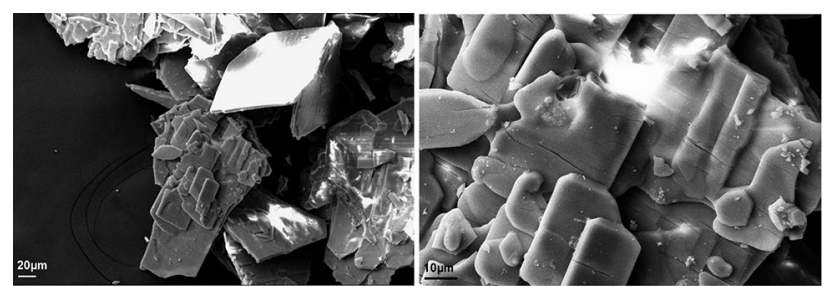

Fig. $12 \mathrm{SEM}$ picture of $\mathrm{Co}_{2} \mathrm{O}_{1.25+\delta}\left(\mathrm{SO}_{4}\right)_{0.75}$

stoichiometry of compound 1 (sulfate:Co $<1: 2$ ). It might be attributed to the thermal decomposition of ammonium sulfate formed during the decomposition of compound $\mathbf{1}$ or $\mathbf{2}$ into basic cobalt sulfates. Compounds $\mathbf{3 a}$ and $\mathbf{3 b}$ have not been prepared and characterized yet. There are four different anhydrous basic cobalt(II) sulfates $\left(2 \mathrm{CoO} \cdot \mathrm{CoSO}_{4}\right.$, [50] $3 \mathrm{CoO} \cdot \mathrm{CoSO}_{4}[51], 4 \mathrm{CoO} \cdot \mathrm{CoSO}_{4}[52]$ and $5 \mathrm{CoO} \cdot \mathrm{CoSO}_{4}$ $[50,53]$ described in the literature. Two among them, the $2 \mathrm{CoO} \cdot \mathrm{CoSO}_{4}$ and the $4 \mathrm{CoO} \cdot \mathrm{CoSO}_{4}$, were only isolated in anhydrous form according to the given formula with heating the primarily formed hydrated basic salt at 415-525 and $292-295^{\circ} \mathrm{C}$, respectively $[50,52]$. The other two references $[50,52]$ gave the $\mathrm{CoO} / \mathrm{SO}_{3}$ ratio only for hydrated salts and did not isolate the anhydrous compounds. The cell parameters of compound $\mathbf{3 a}$ and $\mathbf{3 b}$ could not be determined because they were not enough crystalline to evaluate their diffractograms. Infrared spectrum of compound 3a shows the characteristic tetrahedral sulfate ion frequen$\operatorname{cies}\left(\nu_{\mathrm{s}}=984 \mathrm{~cm}^{-1}, \nu_{\mathrm{as}}=1107,1057 \mathrm{~cm}^{-1}, \delta_{\mathrm{as}}=646,566\right.$, $537 \mathrm{~cm}^{-1}, \mathrm{sh}, \delta_{\mathrm{s}}=465 \mathrm{~cm}^{-1}(\mathrm{sh})$. The Co-O modes are assigned as a wide band system in the far-IR spectrum at
$365 \mathrm{~cm}^{-1}$. The SEM picture can be seen in Fig. 12. Compound 3a occurs as rod-shaped blocks. Its surface is rather smooth, and it has a smaller grain size than the parent compound 2; however, it forms also bigger agglomerates.

The photocatalytic activity of $\mathrm{Co}_{2} \mathrm{O}_{1.25+\delta}\left(\mathrm{SO}_{4}\right)_{0.75}$ (compound 3a) in the degradation of harmful dyes like Methyl orange (MO) and Congo red (CR) was studied at $\mathrm{pH}$ below and above the $\mathrm{pK}_{\mathrm{a}}$ values of the dyes. The methyl orange does not decompose photocatalytically with or without $\mathrm{pH}$ control, while the decomposition of Congo red was found to be reliable. The compound $\mathbf{3 a}$ has $53 \mathrm{~m}^{2} \mathrm{~g}^{-1}$ BET surface area. It shows adsorption capacity toward Congo red (30.7 mg CR g ${ }^{-1}$ of $\mathrm{Co}_{2} \mathrm{O}_{1.25}\left(\mathrm{SO}_{4}\right)_{0.75}$ ). Under irradiation with a UV lamp for $240 \mathrm{~min}$, the pseudo-firstorder reaction rate constants were determined by linear regression of the data considering the Lagergren model at $\mathrm{pH}=5.25$. The apparent rate constant of the reaction $\left(k_{\text {app }}\right)$ was obtained from the slope of the graph representation $-\ln \left(A_{\mathrm{t}} / A_{\mathrm{o}}\right)$ versus time and given in Table 6 . The pseudo-first-order reaction model did not seem real in the case of the acid form of Congo red, probably due to the dissolution of the surface of catalysts in the acid changing the number and type of active sites. At $\mathrm{pH}=5.25$, however, the rate constant was found to be seven times higher than without catalyst (Table 6). Pseudo-second-order equations resulted in negative values of $\mathrm{k}_{2}$, which discloses this relationship from the evaluation of the measured data.

\section{Characterization of final thermal decomposition products $\mathrm{CO}_{3} \mathrm{O}_{4}$ and $\mathrm{CoO}$}

The final decomposition/oxidation product $\left(\mathrm{Co}_{3} \mathrm{O}_{4}\right)$ made at $750{ }^{\circ} \mathrm{C}$ from compound $\mathbf{1}$ in air has a small BET surface area $\left(6 \mathrm{~m}^{2} \mathrm{~g}^{-1}\right)$. It does not result in significant photocatalytic activity for the degradation of either Methyl orange or Congo red dyes. According to SEM images, $\mathrm{Co}_{3} \mathrm{O}_{4}$ shows microcrystalline structure (Figs. 13, 14).

The final decomposition product $(\mathrm{CoO})$ prepared at $800{ }^{\circ} \mathrm{C}$ from compound 1 under $\mathrm{N}_{2}$ atmosphere has a $1 \mathrm{~m}^{2} \mathrm{~g}^{-1} \mathrm{BET}$ surface area. Its SEM pictures show different morphology comparing with the final decomposition product formed in air $\left(\mathrm{Co}_{3} \mathrm{O}_{4}\right)$. It has large sheet-like structure; however, some
Table 6 Photocatalytic activity of compound $\mathbf{3 b}$ in the degradation of Methyl orange and Congo red

\begin{tabular}{llll}
\hline Substrate & $\mathrm{pH}$ & $K_{\mathrm{app}} / 10^{-4} \mathrm{~min}^{-1}$ & $R^{2}$ \\
\hline Congo red, $2 \times 10^{-5} \mathrm{M}$, without catalyst & 3.40 & 1.0 & 0.8108 \\
& 5.25 & 1.0 & 0.9816 \\
Congo red, $2 \times 10^{-5} \mathrm{M}$, with $\mathrm{Co}_{2} \mathrm{O}_{1.25+\delta}\left(\mathrm{SO}_{4}\right)_{0.75}$ catalyst & 3.40 & 2.0 & 0.9117 \\
& 5.25 & 7.0 & 0.9832 \\
Methyl orange, $2 \times 10^{-5} \mathrm{M}$, without catalyst & 3.20 & 0.8 & 0.9940 \\
Methyl orange, with $\mathrm{Co}_{2} \mathrm{O}_{1.25+\delta}\left(\mathrm{SO}_{4}\right)_{0.75}$ catalyst & 5.60 & 0.8 & 0.9964 \\
& 3.17 & 0.6 & 0.9769 \\
& 5.60 & 0.6 & 0.8543 \\
\hline
\end{tabular}




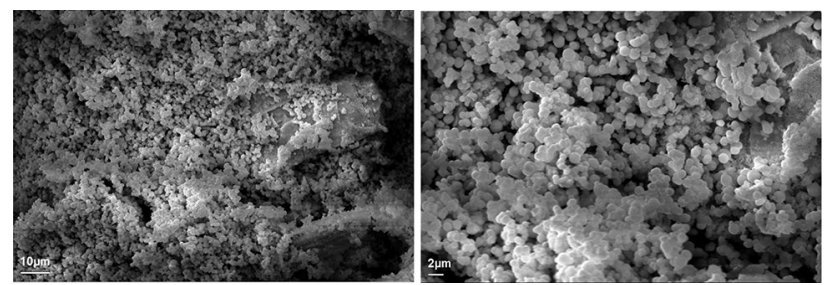

Fig. 13 SEM picture of $\mathrm{Co}_{3} \mathrm{O}_{4}$ crystals made in air at $750{ }^{\circ} \mathrm{C}$
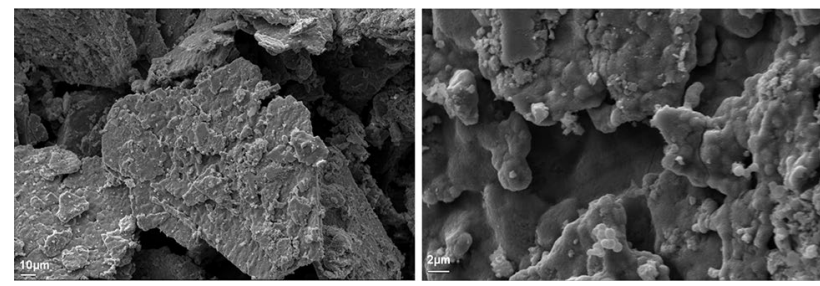

Fig. 14 SEM picture of $\mathrm{CoO}$ formed from compound 1 in inert atmosphere at $800{ }^{\circ} \mathrm{C}$

small spherical particles also observed on the surface of the matrix, similar than the $\mathrm{Co}_{3} \mathrm{O}_{4}$ crystals in Fig. 13.

\section{Conclusions}

Di $\left[\kappa^{1} \mathrm{O}, \kappa^{2} \mathrm{O}\right.$-carbonatotetraamminecobalt(III)] sulfate trihydrate, $\left(\left[\mathrm{Co}\left(\mathrm{NH}_{3}\right)_{4} \mathrm{CO}_{3}\right]_{2} \mathrm{SO}_{4} \cdot 3 \mathrm{H}_{2} \mathrm{O}\right.$ dehydration by isothermic heating at $100{ }^{\circ} \mathrm{C}$ results in $\left[\mathrm{Co}\left(\mathrm{NH}_{3}\right)_{4} \mathrm{CO}_{3}\right]_{2} \mathrm{SO}_{4}$ (compound 2) without alteration of the coordination sphere around. Compound 2 decomposes at $\sim 240{ }^{\circ} \mathrm{C}$ in inert atmosphere giving a decomposition products consists of two modifications of nanosized metallic cobalt (hcp- $15 \mathrm{~nm}$, fcc- $250 \mathrm{~nm})$ and $\mathrm{CoO}(55 \mathrm{~nm})$. The redox reaction results in $\mathrm{N}_{2}$ as an ammonia oxidation product. The decomposition intermediate is a cobalt(II) compound, $\mathrm{Co}_{2} \mathrm{O}_{1,14+\delta}\left(\mathrm{SO}_{4}\right)_{0.86}$ ( $\delta=$ the oxygen surplus due to the presence of $2.8 \%$ of $\mathrm{Co}$ (III) ion). The same reaction in air atmosphere resulted in $\mathrm{Co}_{2} \mathrm{O}_{1.25+\delta}\left(\mathrm{SO}_{4}\right)_{0.75}(\delta=$ the oxygen surplus due to presence of $5.3 \%$ of $\mathrm{Co}(\mathrm{III})$ ion (compound 3a). Compound 3a is oxidized in air at $793{ }^{\circ} \mathrm{C}$ into $\mathrm{Co}_{3} \mathrm{O}_{4}$. The compound 3a exhibits catalytic activity in photodegradation in Congo red. The photodegradation process follows pseudo-first-order kinetic $\left(k_{\text {app }}=1.0\right.$ and 7.0. at $\mathrm{pH}=3.4$ and 5.25, respectively).

Acknowledgements Open access funding provided by Budapest University of Technology and Economics. The research within Project No. VEKOP-2.3.2-16-2017-00013 and GINOP-2.2.1-15-201700084 was supported by the European Union and the State of Hungary, co-financed by the European Regional Development Fund. N. V. M. and P. B. are grateful for the Hungarian Scientific Research Found (K-124544 and K-115762). I. M. Szilágyi thanks for a János Bolyai Research Fellowship of the Hungarian Academy of Sciences and a ÚNKP-18-4-BME-238 grant supported by the New National
Excellence Program of the Ministry of Human Capacities, Hungary. An NRDI K 124212 and an NRDI TNN_16 123631 grants are acknowledged. The research reported in this paper was supported by the Higher Education Excellence Program of the Ministry of Human Capacities in the frame of Nanotechnology and Materials Science research area of Budapest University of Technology (BME FIKP-NAT). B. Barta Holló acknowledges financial support of the Ministry of Education, Science and Technological Development of the Republic of Serbia (Grant No. 451-03-68 $\square / 2020-14 \square / 200125)$.

Open Access This article is licensed under a Creative Commons Attribution 4.0 International License, which permits use, sharing, adaptation, distribution and reproduction in any medium or format, as long as you give appropriate credit to the original author(s) and the source, provide a link to the Creative Commons licence, and indicate if changes were made. The images or other third party material in this article are included in the article's Creative Commons licence, unless indicated otherwise in a credit line to the material. If material is not included in the article's Creative Commons licence and your intended use is not permitted by statutory regulation or exceeds the permitted use, you will need to obtain permission directly from the copyright holder. To view a copy of this licence, visit http://creativecommons.org/licenses/by/4.0/.

\section{References}

1. Sajó IE, Kótai L, Keresztury G, Gács I, Pokol G, Kristóf J, Soptrayanov B, Petrusevski VM, Timpu D, Sharma PK. Studies on the chemistry of tetraamminezinc(II) dipermanganate $\left[\mathrm{Zn}\left(\mathrm{NH}_{3}\right)_{4}\right]\left(\mathrm{MnO}_{4}\right)_{2}$ : Low-temperature synthesis of the manganese zinc oxide $\left(\mathrm{ZnMn}_{2} \mathrm{O}_{4}\right)$ catalyst precursor. Helv Chim Acta. 2008;91(9):1646-8.

2. Kótai L, Banerji KK, Sajó IE, Kristóf J, Sreedhar B, Holly S, Keresztury G, Rockenbauer A. An unprecedented-type intramolecular redox reaction of solid tetraamminecopper(2+) bis(permanganate) $\left(\left[\mathrm{Cu}\left(\mathrm{NH}_{3}\right)_{4}\right]\left(\mathrm{MnO}_{4}\right)_{2}\right)$ - a low-temperature synthesis of copper dimanganese tetraoxide-type $\left(\mathrm{CuMn}_{2} \mathrm{O}_{4}\right)$ nanocrystalline catalyst precursors. Helv Chim Acta. 2002;85(8):2316-27.

3. Kótai L, Sajó IE, Jakab E, Keresztury G, Németh C, Gács I, Menyhárt A, Kristóf J, Hajba L, Petrusevski VM, Ivanovski D, Timpu D, Sharma PK. Studies on the chemistry of $\left[\mathrm{Cd}\left(\mathrm{NH}_{3}\right)_{4}\right]\left(\mathrm{MnO}_{4}\right)_{2}$. A lowtemperature synthesis route of the $\mathrm{CdMn}_{2} \mathrm{O}_{4+\mathrm{x}}$ type $\mathrm{NO}_{\mathrm{x}}$ and $\mathrm{CH}_{3} \mathrm{SH}$ sensor precursors. Z Anorg Allgem Chem. 2012;638(1):177-86.

4. Kovács GB, May NV, Bombicz PA, Klébert S, Németh P, Menyhárd A, Novodárszki G, Petrusevski V, Franguelli FP, Magyari J, Béres K, Szilágyi IM, Kótai L. An unknown component of a selective and mild oxidant: structure and oxidative ability of a double salt-type complex having $\kappa^{1} \mathrm{O}$-coordinated permanganate anions and three-and four-fold coordinated silver cations. RSC Adv. 2019;9(49):28387-98.

5. Holló BB, Petruševski VM, Kovács GB, Franguelli FP, Farkas A, Menyhárd A, Lendvay G, Sajó IE, Nagy-Bereczki L, Pawar RP, Szilágyi IM, Bódis E, Kótai L. Thermal and spectroscopic studies on a double-salt-type pyridine-silver perchlorate complex having $\kappa^{1}-\mathrm{O}$ coordinated perchlorate ions. J Therm Anal Calorim. 2019;138(2):1193-205.

6. Sajó IE, Kovács GB, Pasinszki T, Bombicz PA, May Z, Szilágyi IM, Jánosity A, Banerji KK, Kant R, Kótai L. The chemical identity of " $\left[\mathrm{Ag}(\mathrm{py})_{2}\right] \mathrm{MnO}_{4}$ " organic solvent soluble oxidizing agent and new synthetic routes for the preparation of $\left[\mathrm{Ag}(\mathrm{py})_{\mathrm{n}}\right]$ $\mathrm{XO}_{4}(\mathrm{X}=\mathrm{Mn}, \mathrm{Cl}$, and Re, $n=2-4)$ complexes. J Coord Chem. 2018;71(16-18):2884-904.

7. Kótai L, Fodor J, Jakab E, Sajó IE, Szabó P, Lónyi F, Valyon J, Gács I, Argay G, Banerji KK. A thermally induced 
low-temperature intramolecular redox reaction of bis (pyridine) silver (I) permanganate and its hemipyridine solvate. Transit Met Chem. 2006;31(1):30-4.

8. Górska N, Mikuli E, Kótai L. Spectroscopic, structural and thermal characterization of crystalline $\left[\mathrm{Cr}\left(\mathrm{OC}\left(\mathrm{NH}_{2}\right)_{2}\right)_{6}\right]$ $\mathrm{X}_{3}\left(\mathrm{X}=\mathrm{ClO}_{4}, \mathrm{BF}_{4}\right.$ and $\left.\mathrm{Cl}\right)$ complexes. Eur Chem Bull. 2014;3(5):474-81.

9. Mansouri M, Atashi H, Tabrizi FF, Mirzaei AA. Kinetics studies of nano-structured cobalt-manganese oxide catalysts in FischerTropsch synthesis. J Ind Eng Chem. 2013;19(4):1177-83.

10. Mansouri M, Atashi H, Khalilipour MM, Setareshenas N, Shahraki F. Rate expression of Fischer-Tropsch synthesis over Co-Mn nanocatalyst by response surface methodology (RSM). J Korean Chem Soc. 2013;57(6):769-77.

11. Vortmann G. Zur Kenntniss der Kobaltammonium-Verbindungen. Ber Dtsch Chem Ges. 1877;10(2):1451-9.

12. Strock LW, McCutcheon TP. The crystalline form of some new cobaltammines. J Am Chem Soc. 1931;53(8):2852-66.

13. Udovenko VV, Gerasenkova AN. Monoethanolamine complexes of cobalt. Zh Neorg Khim. 1966;11(9):2066-9.

14. Hara R. Studies on the precipitation reactions of some metallic complex salts towards proteins. Yakugaku Zasshi. 1952;72(6):748-56.

15. Konoshita K. Feeding fungi with cobaltammine complex salts. Acta Phytochim. 1927;3:31-49.

16. Jaeger FM. Beiträge zur Krystalldiagnose der Kobaltverbindungen mit complexen Ionen. Z Kristallogr Cryst Mater. 1904;39(1-6):541-75.

17. Flint EE. Goniometric investigations. I. $\left[\mathrm{Co}\left(\mathrm{NH}_{3}\right)_{4} \mathrm{CO}_{3}\right]_{2} \mathrm{SO}_{4} \cdot 3 \mathrm{H}_{2} \mathrm{O}$. Trudy Instituta Kristallografiya. Akademiya Nauk SSSR. 1947;3:11-2.

18. Strock LW. The crystallography and space group of carbonatotetraamminecobaltic sulfate. Z Kristallog Kristallgeom Krystallphys Kristallchemie. 1933;86:45-52.

19. Amigó JM, Torras CM. Constantes cristalográficas del $\left[\mathrm{CoCO}_{3}\left(\mathrm{NH}_{3}\right)_{4}\right]_{2} \mathrm{SO}_{4} 3 \mathrm{H}_{2} \mathrm{O}$. Acta Geol Hisp. 1973;8(5):165-6.

20. Macikenas D, Hazell RG, Christensen AN. X-ray crystallographic study of tetraamminecarbonatocobalt(III) sulfate trihydrate, $\left[\mathrm{Co}\left(\mathrm{NH}_{3}\right)_{4} \mathrm{CO}_{3}\right]_{2} \mathrm{SO}_{4} \cdot 3 \mathrm{H}_{2} \mathrm{O}$. Acta Chem Scand. 1995;49(9):636-9.

21. Amigó JM, Garcia-González J, Miravitlles C. Thermal behaviour of $\left[\mathrm{CoCO}_{3}\left(\mathrm{NH}_{3}\right)_{4}\right]_{2} \mathrm{SO}_{4} 3 \mathrm{H}_{2} \mathrm{O}$. J Therm Anal Calorim. 1971;3(2):169-76.

22. Onodera S. Gas-chromatographic studies of the thermal decompositions of carbonato-pentaammine-, carbonatotetraammine-, and dicarbonato-diamminecobalt (III) complexes in the solid state. Bull Chem Soc Jpn. 1978;51(6):1889-90.

23. Vortmann G, Blasberg O. Zur Kenntniss der Kobaltoctaminsalze. Ber Dtsch Chem Ges. 1889;22(2):2648-55.

24. Benrath A, Kohlberg W. Hydrated salts of complex cobalt bases. Z Anorg Allg Chem. 1924;138:65-77.

25. Jörgensen SM. Zur Konstitution der Kobalt-, Chrom-und Rhodiumbasen. Z Anorg Chem. 1894;7(1):289-330.

26. Uspensky A, Tschibisoff K. Die Untersuchung einiger Ersatzreaktionen in der inneren Sphäre der Komplexverbindungen. Z Anorg Allg Chem. 1927;164(1):335-40.

27. Komarova AV, Pyartman AK, Kolobov NP, Mironov VE. Outerspheric association of cobalt(III) carbonatotetraamine with anions. Zh Fiz Khim. 1974;48(4):1035-6.

28. Schwarz R, Tede K. Über die Photochemie der Komplexverbindungen (II). Ber Dtsch Chem Ges. 1927;60(B):63-9.

29. Ephraim F. Über die Löslichkeit von Kobaltiaken. (8. Beitrag zur Kenntnis der Löslichkeit.). Ber Dtsch Chem Ges. 1923;56(7):1530-42.

30. Erdey L. Titrimetric analysis. Budapest: Akadémia Kiadó; 1958 (in Hungarian).
31. Erdey L. Gravimetric analysis I-III. Budapest: Akadémia Kiadó; 1960 (in Hungarian).

32. Siebert H. Ultrarotspektren von Kobalt (III)-Komplexen mit Ammoniak und Resten von Sauerstoffsäuren als Liganden. Z Anorg Allg Chem. 1959;298(1-2):51-63.

33. Goldsmith JA, Hezel A, Ross SD. The skeletal vibrations of some cobalt (III) carbonato-, phosphato-and sulphato-complexes. Spectrochim Acta A. 1968;24(8):1139-47.

34. Goldsmith JA, Ross SD. Factors affecting the infra-red spectra of planar anions with D3h symmetry-IV the vibrational spectra of some complex carbonates in the region $4000-400 \mathrm{~cm}^{-1}$. Spectrochim Acta A. 1968;24(8):993-8.

35. Batsanov SS. Refraction of the hydrogen bond in inorganic compounds. Z Fiz Khim. 1960;34(1):68-77.

36. Dunell BA, Pachal MD, Ulrich SE. A study of thermal motion of ammine groups in carbonatotetramminecobalt (III) sulfate. Can J Chem. 1973;51(7):1107-8.

37. Ferraro JR. Low-frequency vibrations of inorganic and coordination compounds. New York: Plenum Press; 1971.

38. Fujita J, Martell AE, Nakamoto K. Infrared spectra of metal chelate compounds. VIII. Infrared spectra of Co(III) carbonato complexes. J Chem Phys. 1962;36(2):339-45.

39. Nakamoto K. Infrared and Raman spectra of inorganic and coordination compounds—-part A and B. 6th ed. Hoboken: Wiley; 2009.

40. Sajó IE, Bakos LP, Szilágyi IM, Lendvay G, Magyari J, Mohai M, Szegedi A, Farkas A, Jánosity A, Klébert S, Kótai L. Unexpected sequential $\mathrm{NH}_{3} / \mathrm{H}_{2} \mathrm{O}$ solid/gas phase ligand exchange and quasi-intramolecular self-protonation yield $\left[\mathrm{NH}_{4} \mathrm{Cu}(\mathrm{OH}) \mathrm{MoO}_{4}\right]$, a photocatalyst misidentified before as $\left(\mathrm{NH}_{4}\right)_{2} \mathrm{Cu}\left(\mathrm{MoO}_{4}\right)_{2}$. Inorg Chem. 2018;57(21):13679-92.

41. Sastri VS, Langford $\mathrm{CH}$. Electronic spectra of carbonato and oxalato ammine complexes of cobalt (III); average field model for singlet, triplet, and charge transfer bands. Can J Chem. 1969;47(22):4237-40.

42. Sastri VS. Studies on the disposition of carbonato group in cobalt (III) complexes. Inorg Chim Acta. 1972;6:264-6.

43. Schutte CJH, Heyns AM. Low-temperature studies. IV. The phase transitions of ammonium sulfate and ammonium- $\mathrm{d}_{4}$ sulfate; the nature of hydrogen bonding and the reorientation of the $\mathrm{NX}_{4}^{+}$ ions. J Chem Phys. 1970;52(2):864-71.

44. Kótai L, Horváth T, Szentmihályi K, Keszler A. Evidence for quasi-intramolecular acid-base reactions in solutions of transition metal ammine complexes. Transit Met Chem. 2000;25:293-4.

45. Ray AE, Smith SR, Scofield JD. Study of the phase transformation of cobalt. J Phase Equilib. 1991;12(6):644-7.

46. Kótai L, Gács I, Sajó IE, Sharma PK, Banerji KK. Beliefs and facts in permanganate chemistry-an overview on the synthesis and the reactivity of simple and complex permanganates. Trend Inorg Chem. 2009;42(13):25-104.

47. Kocsis T, Magyari J, Sajó IE, Pasinszki T, Homonnay Z, Szilágyi IM, Farkas A, May Z, Effenberger H, Szakáll S, Pawar RP, Kótai L. Evidence of quasi-intramolecular redox reactions during thermal decomposition of ammonium hydroxodisulfitoferriate(III), $\left(\mathrm{NH}_{4}\right)_{2}\left[\mathrm{Fe}(\mathrm{OH})\left(\mathrm{SO}_{3}\right)_{2}\right] \mathrm{H}_{2} \mathrm{O}$. J Therm Anal Calorim. 2018;132(1):493-502.

48. Kristóf J, Horváth A, Szabó P. Simultaneous thermoanalytical investigations on the rapid decomposition of pentamminecobalt (III) complexes. J Therm Anal. 1990;36(3):1191-204.

49. Wendlandt WW, Smith JP. The thermal decomposition of metal complexes-VII A thermomagnetic study of the $\mathrm{Co}$ (III) $\rightarrow \mathrm{Co}$ (II) reduction in cobalt(III) ammine complexes (1). J Inorg Nucl Chem. 1963;25(10):1267-72.

50. Dubler E, Oswald HR. New lower basic cobalt sulfate, $\mathrm{Co}_{3}(\mathrm{OH})_{2}\left(\mathrm{SO}_{4}\right)_{2} \cdot 2 \mathrm{H}_{2} \mathrm{O}$. Naturwissenschaften. 1969;56(6):327.

51. Pickering SU. The interaction of metallic sulphates and caustic alkalis. J Chem Soc Trans. 1907;91:1981-8. 
52. Haberman J. Über einige basische Salze. Monatsch Chem. 1884;5:432-50.

53. Strömholm D. Studier öfver amorfa faellningar II. Om basiska salter af tvavarda metalloxider. Ark Kem Miner Geol. 1905/7;2(16):1-13.
Publisher's Note Springer Nature remains neutral with regard to jurisdictional claims in published maps and institutional affiliations. 